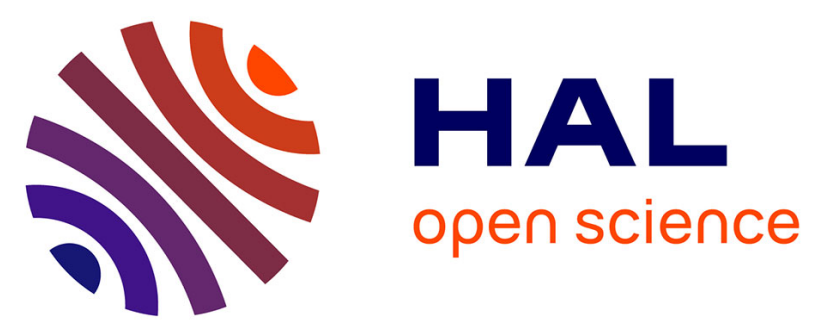

\title{
Post-translational remodeling of ryanodine receptor induces calcium leak leading to Alzheimer's disease-like pathologies and cognitive deficits
}

Alain Lacampagne, Xiaoping Liu, Steven Reiken, Renaud Bussiere, Albano C Meli, Inger Lauritzen, Andrew Teich, Ran Zalk, Nathalie Saint, Ottavio Arancio, et al.

\section{To cite this version:}

Alain Lacampagne, Xiaoping Liu, Steven Reiken, Renaud Bussiere, Albano C Meli, et al.. Posttranslational remodeling of ryanodine receptor induces calcium leak leading to Alzheimer's diseaselike pathologies and cognitive deficits. Acta Neuropathologica, 2017, 134 (5), pp.749 - 767. 10.1007/s00401-017-1733-7 . hal-01832793

\section{HAL Id: hal-01832793 \\ https://hal.umontpellier.fr/hal-01832793}

Submitted on 17 Dec 2019

HAL is a multi-disciplinary open access archive for the deposit and dissemination of scientific research documents, whether they are published or not. The documents may come from teaching and research institutions in France or abroad, or from public or private research centers.
L'archive ouverte pluridisciplinaire HAL, est destinée au dépôt et à la diffusion de documents scientifiques de niveau recherche, publiés ou non, émanant des établissements d'enseignement et de recherche français ou étrangers, des laboratoires publics ou privés. 


\title{
Post-translational remodeling of ryanodine receptor induces calcium leak leading to Alzheimer's disease-like pathologies and cognitive deficits
}

\author{
Alain Lacampagne ${ }^{2} \cdot$ Xiaoping Liu $^{1} \cdot$ Steven Reiken $^{1} \cdot$ Renaud Bussiere $^{3} \cdot$ Albano C. Meli $^{2} \cdot$ Inger Lauritzen $^{3} \cdot$ \\ Andrew F. Teich ${ }^{4} \cdot$ Ran Zalk $^{1} \cdot$ Nathalie Saint $^{2} \cdot$ Ottavio Arancio $^{4} \cdot$ Charlotte Bauer $^{3} \cdot$ Fabrice Duprat $^{3}$. \\ Clark A. Briggs ${ }^{5} \cdot$ Shreaya Chakroborty $^{5}$ - Grace E. Stutzmann ${ }^{5} \cdot$ Michael L. Shelanski $^{4} \cdot$ Frederic Checler $^{3}$. \\ Mounia Chami $^{3}$ - Andrew R. Marks ${ }^{1}$
}

\begin{abstract}
The mechanisms underlying ryanodine receptor (RyR) dysfunction associated with Alzheimer disease (AD) are still not well understood. Here, we show that neuronal RyR2 channels undergo post-translational remodeling (PKA phosphorylation, oxidation, and nitrosylation) in brains of $\mathrm{AD}$ patients, and in two murine models of $\mathrm{AD}\left(3 \times \mathrm{Tg}-\mathrm{AD}, A P P^{+/} / P S 1^{+/-}\right)$. RyR2 is depleted of calstabin2 (KFBP12.6) in the channel complex, resulting in endoplasmic reticular (ER) calcium $\left(\mathrm{Ca}^{2+}\right)$ leak. RyRmediated ER $\mathrm{Ca}^{2+}$ leak activates $\mathrm{Ca}^{2+}$-dependent signaling pathways, contributing to $\mathrm{AD}$ pathogenesis. Pharmacological (using a novel RyR stabilizing drug Rycal) or genetic rescue of the RyR2-mediated intracellular $\mathrm{Ca}^{2+}$ leak improved synaptic plasticity, normalized behavioral and cognitive functions and reduced $A \beta$ load. Genetically altered mice with congenitally leaky RyR 2 exhibited
\end{abstract}

Alain Lacampagne, Xiaoping Liu and Steven Reiken contributed equally to this work and are co-first authors.

Frederic Checler, Mounia Chami and Andrew R. Marks contributed equally to this work and are co-senior authors. premature and severe defects in synaptic plasticity, behavior and cognitive function. These data provide a mechanism underlying leaky RyR2 channels, which could be considered as potential AD therapeutic targets.

Keywords Calcium - Amyloid beta Ryanodine receptor $2 \cdot$ Oxidative stress $\cdot$ PKA-dependent phosphorylation

\section{Introduction}

Alzheimer's disease (AD) is characterized by an overload of toxic amyloid beta $(A \beta)$ peptides in the brain associated with premature onset of cognitive dysfunction. Modulation of $A \beta$ peptide production is a consistent finding in a subset of autosomal-dominant familial AD cases (FAD) due to mutations of $\beta$ amyloid precursor protein ( $\beta$ APP) or $\gamma$-secretase/presenilins (PS1 or PS2).

A "calcium $\left(\mathrm{Ca}^{2+}\right)$ hypothesis" of $\mathrm{AD}$ has been proposed, whereby $\beta$ APP and PS1/2 mutations have been linked to alterations in $\mathrm{Ca}^{2+}$ handling $[10,20$, 78] that disrupt key mechanisms involved in learning and memory [6]. Increased cytosolic $\left[\mathrm{Ca}^{2+}\right]$ has been

3 Université Côte d'Azur, INSERM, CNRS, IPMC, Laboratory of Excellence DistALZ, 06560 Sophia-Antipolis, Valbonne, France

4 Department of Pathology and Cell Biology, Taub Institute for Research on Alzheimer's Disease and the Aging Brain and Department of Pathology and Cell Biology, Columbia University College of Physicians and Surgeons, New York, NY 10032, USA

5 Department of Neuroscience, Rosalind Franklin University/ Chicago Medical School, North Chicago, IL 60064, USA 
proposed to involve both enhanced $\mathrm{Ca}^{2+}$ entry via receptor-operated channels on the plasma membrane (e.g., NMDARs) [81] and increased release of $\mathrm{Ca}^{2+}$ from the endoplasmic reticulum (ER) via ryanodine receptors (RyR) that regulate ER $\mathrm{Ca}^{2+}$ release [28] and inositol 1,4,5-trisphosphate receptors $\left(\mathrm{IP}_{3} \mathrm{R}\right)[13,15$, $20,65,74]$. RyR dysfunction has been reported in AD animal models [11, 58, 63]. However, the molecular mechanisms underlying RyR dysfunction in $\mathrm{AD}$ remain poorly understood.

RyRs are a family of three known mammalian isoforms: RyR1, RyR2 and RyR3, which are classified as "skeletal muscle", "heart" and "brain" types. Although all isoforms can be found in the brain, the RyR2 isoform is predominantly expressed in the cerebral cortex and dentate gyrus of the hippocampus [32]. RyRs are homotetramers in which each protomer of the channel has a molecular mass of $565 \mathrm{kDa}$, with $4 / 5$ of the channel comprising a huge $\mathrm{N}$-terminal cytoplasmic domain that serves as a scaffold for channel regulators, while the remainder of the channel forms the pore and associated transmembrane portions [70].

Enhanced RyR-mediated ER $\mathrm{Ca}^{2+}$ leak is linked to pathophysiological post-translational modifications in the macromolecular complex [48]. Here, we show that neuronal RyR2 channels undergo post-translational remodeling characterized by PKA phosphorylation, oxidation/nitrosylation and depletion of the channel stabilizing subunit calstabin2 (FKBP12.6) in human sporadic $\mathrm{AD}, A P P^{+/-} / P S 1^{+/-}$(APP-K670N/ M671L, PS1-M146V) and $3 \times$ Tg-AD (Tau-P301L, APP-K670N/M671L， PS1-M146V) transgenic mice. RyR2 channel remodeling results in an $\mathrm{ER} \mathrm{Ca}^{2+}$ leak that activates $\mathrm{Ca}^{2+}$-dependent signaling pathways which are altered in AD. Fixing the leaky RyR2 channels with an oral administration of Rycal S107, which prevents stress-induced dissociation of calstabin 2 from the RyR2 complex [85], inhibited calpain activity and AMPKdependent tau phosphorylation, improved hippocampal synaptic plasticity (LTP and LTD) and cognitive function, and diminished neuropathology (reduced plaques) in the $A P P^{+/-} / P S 1^{+/-}$and $3 \times \mathrm{Tg}-\mathrm{AD}$ brains. Moreover, crossing $A P P^{+/-} / P S 1^{+/-}$mice with $R y R 2-S 2808 A^{+/+}$ knock-in mice, harboring RyR2 channels that cannot be PKA phosphorylated, resulted in improved cognitive function and decreased neuropathology. In contrast, mice harboring constitutively leaky PKA phosphomimetic RyR2-S2808D ${ }^{+/+}$channels exhibited early cognitive and synaptic dysfunction.

Taken together, our data show that remodeling of the RyR2 macromolecular complex may contribute to altered $\beta$ APP metabolism and AD pathogenesis.

\section{Materials and methods}

\section{In vivo animal models}

We used male and female C57BL/6-SJLF1-APP ${ }^{+/-}$/ $C 57 B L / 6-D 2 F 1-P S 1^{+/-}$double transgenic mice that express two human FAD mutations, presenilin 1 (PS1- M146V) [22] and the double Swedish APP mutation [(HuAPP695. K670N-M671L) 2576: APPswe] [38], RyR2-S2808D $D^{+/+}$ [72], RyR2-S2808A ${ }^{+/+}$[73] knock-ins (C57BL/6 back-

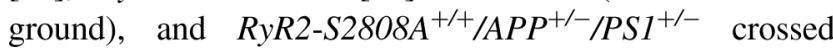
mice. We also used female $3 \times \mathrm{Tg}-\mathrm{AD}$ mice obtained by pronuclear microinjection of two independent transgene constructs encoding human APPswe and tau-P301L $(4 \mathrm{R} / 0 \mathrm{~N})$, both under the control of the mouse Thy1.2-regulatory elements, into single-cell embryos harvested from mutant homozygous (PS1-M146V) knock-in mice [57]. We used male and female WT littermate controls C57BL/6SJLF1 for the $A P P^{+/-}$mice, C57BL/6-D2F1 for the PS1 $P S 1^{+/-}$mice, C57BL/6 for the RyR2-S2808A mice, RyR2-

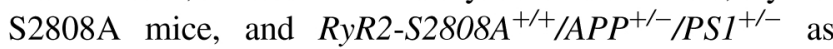
well, and females 129/C57BL6 for $3 \times$ Tg-AD mice. All animal models were housed in the SPF animal facility.

S107 $(75 \mathrm{mg} / \mathrm{kg} /$ day $)$ was delivered to the mice in the drinking water to $A P P^{+/-} / P S 1^{+/-}$from 4 weeks of age until testing at 3 months of age, or until 5 months. We used 6-month-old $A P P^{+/-} / P S 1^{+/-}$mice for neuropathology examinations, including plaques and gliosis analyses. 11-month-old $3 \times \mathrm{Tg}$-AD mice were treated orally for 4 weeks with S107. "S2808D $\mathrm{D}^{+/++}$mice were treated orally with $\mathrm{S} 107$ in the drinking water from 4 weeks until testing at 2 months (F0), or continuously for two generations (F2) and were tested at 2 months. S107 was also used in previous studies $[3,5,54]$ and was administered subcutaneously by implanting osmotic pumps or mixed in drinking water. These studies did not reveal any toxicity related to S107 treatment. Investigators were blinded with respect to genotypes and treatments.

For biochemical analyses, mice were euthanized by cervical dislocation prior to dissection and brain isolation. The Isolated brains were snap-frozen in liquid nitrogen. For immunohistochemistry analyses, mice were anesthetized with a ketamine/xylazine mixture and cardiac perfusion was then applied with PBS for $5 \mathrm{~min}$ and then with $10 \mathrm{ml}$ PFA $4 \%$ solution. Brains were post-fixed in PFA $4 \%$ for $24 \mathrm{~h}$.

\section{Human samples}

Human brain samples were provided by the Department of Pathology, Columbia University College of Physician and Surgeons. Cases were de-identified, but information was provided regarding age at death and neuropathology 
(see supplementary Table I). Brain samples were stored at $-80{ }^{\circ} \mathrm{C}$. Approximately, $1 \mathrm{~g}$ of tissue was homogenized in $10 \mathrm{ml}$ of $10 \mathrm{mM}$ Tris-maleate buffer containing protease and phosphatase inhibitors (Roche diagnostics). The homogenates were centrifuged at $10,000 \times g$ and the supernatants collected.

\section{Biochemistry measurements for RyR2 channel remodeling}

The isolation of mouse brain microsomes has been described previously [48, 52]. Briefly, mouse and human RyR2 were immunoprecipitated from the brain lysate with an RyR2 specific antibody $(2 \mu \mathrm{g})$ in $0.5 \mathrm{ml}$ of a modified RIPA buffer (50 mM Tris- $\mathrm{HCl} \mathrm{pH} 7.2,0.9 \% \mathrm{NaCl}, 5.0 \mathrm{mM}$ $\mathrm{NaF}, 1.0 \mathrm{mM} \mathrm{Na} 3 \mathrm{VO} 4,1 \%$ Triton- X100, and protease inhibitors) and left overnight at $4{ }^{\circ} \mathrm{C}$. The RyR2 specific antibody is an affinity-purified polyclonal rabbit antibody, custom-made by Yenzym Antibodies (San Francisco, CA) using the peptide CKPEFNNHKDYAQEK corresponding to amino acids $1367-1380$ of mouse RyR2 with a cysteine residue added to the amino terminus. This antibody recognizes both human and mouse RyR2. The immune complexes were incubated with protein A Sepharose beads (Sigma, St. Louis, MS) at $4{ }^{\circ} \mathrm{C}$ for $1 \mathrm{~h}$ and the beads were washed three times with RIPA buffer. Immunoprecipitates were size-fractionated on SDS-PAGE gels ( $6 \%$ for RyR, $10 \%$ for PDE $4,12 \%$ for PKA, PP2A, and PP1, and $15 \%$ for calstabin) and transferred onto nitrocellulose membranes for $2 \mathrm{~h}$ at $200 \mathrm{~mA}$. Immunoblots were developed using the primary antibodies described in supplementary materials.

\section{Endoplasmic reticulum (ER) calcium $\left(\mathrm{Ca}^{2+}\right)$ leak assay}

The ER $\mathrm{Ca}^{2+}$ leak assay has been previously described [17, 48]. Briefly, $50 \mu \mathrm{g} / \mathrm{ml}$ brain microsomes was diluted into a buffer ( $\mathrm{pH}$ 7.2) containing $8 \mathrm{mM}$ K-phosphocreatine and 2 units/ml of creatine kinase mixed with $3 \mu \mathrm{M}$ Fluo-3. $\mathrm{Ca}^{2+}$ loading of the microsomes was initiated by adding $1 \mathrm{mM}$ ATP. After $\mathrm{Ca}^{2+}$ uptake to saturation, $3 \mu \mathrm{M}$ thapsigargin was added to block $\mathrm{Ca}^{2+}$ uptake. $\mathrm{Ca}^{2+}$ leaking out of the ER was detected as an increase in $\mathrm{Ca}^{2+}$ fluorescence, and ryanodine $(10 \mu \mathrm{M})$ was added to block the RyR channels and confirm that the leak was via RyR. Changes in the emission of Fluo-3 after excitation at $485 \mathrm{~nm}$ were measured by a fluorescence spectrophotometer (Photon Technology International, PTI) and the changes of fluorescence intensity were recorded using "FeliX version 2" software (PTI).

\section{Single-channel data acquisition and analysis}

ER vesicles containing RyR were fused to planar lipid bilayers formed by painting a lipid mixture of phosphatidylethanolamine and phosphatidylcholine (Avanti Polar Lipids) in a 3:1 ratio in decane, across a 200-mm hole in polysulfonate cups (Warner Instruments) separating two chambers. The trans-chamber $(1 \mathrm{ml})$, representing the intra-SR (luminal) compartment, was connected to the head stage input of a bilayer voltage clamp amplifier. The cis-chamber $(1 \mathrm{ml})$, representing the cytoplasmic compartment, was held at virtual ground. Solutions used were as follows: $1 \mathrm{mM}$ EGTA, 250/125 mM HEPES/Tris, $50 \mathrm{mM}$ $\mathrm{KCl}, 0.64 \mathrm{mM} \mathrm{CaCl} 2, \mathrm{pH} 7.35$ as cis-solution and $53 \mathrm{mM}$ $\mathrm{Ca}(\mathrm{OH}) 2,50 \mathrm{mM} \mathrm{KCl}, 250 \mathrm{mM}$ HEPES, pH 7.35 as transsolution. The concentration of free $\mathrm{Ca}^{2+}$ in the cis-chamber was calculated with WinMaxC program (version 2.50; www.stanford.edu/_cpatton/maxc.html). ER vesicles were added to the cis-side, and fusion with the lipid bilayer was induced by making the cis-side hyperosmotic by the addition of $400-500 \mathrm{mM} \mathrm{KCl}$. After the appearance of potassium and chloride channels, the $c i s$-side was perfused with the cis-solution. Single-channel currents were recorded at $0 \mathrm{mV}$ using a Bilayer Clamp BC-525D (Warner Instruments, LLC, CT), filtered at $1 \mathrm{kHz}$ using a Low-Pass Bessel Filter 8 Pole (Warner Instruments, LLC, CT), and digitized at $4 \mathrm{kHz}$. To confirm RyR identity, $5 \mu \mathrm{M}$ ryanodine was added to the cis-side at the end of the experiments. All experiments were performed at room temperature $\left(23 \pm 2{ }^{\circ} \mathrm{C}\right)$. Single-channel Po was determined over 2 min of continuous recording using the method of $50 \%$ threshold analysis [16]. The recordings were analyzed using Clampfit 10.1 (Molecular Devices) and Prism (ver.5.0, GraphPad).

\section{Electrophysiology}

Electrophysiological recordings were performed by stimulating Schaeffer collateral fibers and recording in the CA1 stratum radiatum [55]. Basal responses were recorded for $30 \mathrm{~min}$. Long-term depression (LTD) was induced by low-frequency stimulation (LFS) consisting of 900 pulses at $1 \mathrm{~Hz}$. Responses were recorded for $120 \mathrm{~min}$ after LFS and measured as the slope of field-excitatory postsynaptic potential (fEPSP) and expressed as the percentage of baseline. Basal synaptic transmission (BST) was assayed by plotting the stimulating voltage (V) to fEPSP slopes to generate input-output relations. The results were expressed as mean \pm standard error (SEM). One-way ANOVA was applied for data analysis.

\section{Behavioral studies}

\section{Fear conditioning}

Contextual and cued fear conditioning memories were evaluated as described previously with some modifications 
$[33,42,62]$. On day 1 , mice were exposed to a context of 2 min duration followed by a $85 \mathrm{~dB}$ tone at $2800 \mathrm{~Hz}$ for $30 \mathrm{~s}$ as a conditioning stimulus (CS), with $2 \mathrm{~s}$ of $0.80 \mathrm{~mA}$ foot shock [unconditioned stimulus (US)] at the end of the CS. Mice were taken back to the home cages $30 \mathrm{~s}$ after the shock. Freezing was measured immediately after the end of the shock for $30 \mathrm{~s}$ using the Freezeview software (MED Associates Inc.). The contextual memory (total freezing) was measured after $24 \mathrm{~h}$ when mice were re-exposed to the same context for $5 \mathrm{~min}$ (no tone, no shock). The cued fear memory was measured on day 3 . Mice were placed in a novel context for $2 \mathrm{~min}$ (pre-CS test) followed by $3 \mathrm{~min}$ of tone (CS test, $85 \mathrm{~dB}$ tone at $2800 \mathrm{~Hz}$ ). Freezing during the first $2 \mathrm{~min}$ and the last $3 \mathrm{~min}$ were measured separately. A digital video camera was installed inside the conditioning chamber $(72 \mathrm{~cm} \times 51 \mathrm{~cm} \times 48 \mathrm{~cm})$ and connected to Freezeframe software (MED Associates Inc.). The amount of freezing was recorded by the software as cumulative duration of the inactive state.

\section{Other behavioral tests}

Morris water maze (MWM), novel object recognition (NOR), elevated plus maze (EPM), and open field test (OF) were performed as described previously $[48,58]$.

\section{Immunohistochemistry}

$\mathrm{A} \beta$ deposits were quantified in APP/PS1 mice in both the hippocampus and cortex regions using $6 \mathrm{E} 10$ primary antibody (recognizing A $\beta$, C99 and total APP) (Biocare Medical, CA) at 1:400 dilution with Ventana machines (Ventana Medical Systems, Inc.). A $\beta$ plaques were counted from six slices per mouse and three mice per group. Coronal sections of paraffin-embedded brains were selected with an interval of $56 \mu \mathrm{m}$ (each section is $8 \mu \mathrm{m}$ ) to cover the same brain regions. For astrocyte staining, we used EP672Y clone GFAP antibody with Benchmark Ultra Platform machines (Ventana Medical Systems, Inc.).

In the $3 \times$ Tg-AD model, A $\beta$ deposits were predominantly restricted to the hippocampus [57] and detected using $6 \mathrm{E} 10$ primary antibody. In this model, we used vibratome coronal brain sections $(50 \mu \mathrm{m}$ depth for each section, with an interval of $50 \mu \mathrm{m})$. We counted $\mathrm{A} \beta$ plaques from four slices per mouse, three mice per group. The analyzed sections covered the whole subiculum region. We also used: (i) APP C-terminal antibody (A8717, Sigma-Aldrich) recognizing 676-695 residues of total APP, APP C-terminal fragments (CTF:C99 and C83), and APP intracellular domain (AICD) at 1:1000 dilution, and (ii) FCA18 antibody [4] recognizing specifically the first aspartyl residue of $A \beta$, and C99 at 1:1000 dilution. Nuclei were detected using DAPI dye at 1:10,000 dilution. For $A \beta$ plaques quantification, we counted extracellular senile plaques with dense $A \beta$ core (mature plaques). We excluded low and diffuse extracellular staining.

\section{$A \beta 40$ and $A \beta 42$ peptide measurements}

$A \beta 40$ and $A \beta 42$ peptide levels from total brain (in APP/ PS1) or total hippocampal $(3 \times \mathrm{Tg}-\mathrm{AD})$ lysates were measured with an ELISA kit (Wako Chemicals USA, Inc., or NOVEX ${ }^{\mathrm{TM}}$, ThermoFisher Scientific, France) using human C-terminus $A \beta$ antibodies. The same quantity of total protein extracts was dissolved in $5 \mathrm{M}$ guanidine $\mathrm{HCl} / 50 \mathrm{mM}$ Tris $\mathrm{HCl}, \mathrm{pH} 8.0$, to yield detection of both soluble and insoluble $A \beta 42$ peptides.

\section{SDS-PAGE and western blot analyses}

Whole brain homogenates $(50 \mu \mathrm{g})$ were size-fractionated on SDS-PAGE gels (4-20\%) and transferred onto nitrocellulose membranes. Immunoblots were developed using the antibodies described in supplementary materials.

\section{Measurements of spine density and diameter}

Rat E18 (embryonic day 18) hippocampal neurons were isolated and cultured for 21 days before the experiment using previously established culture conditions and experimental procedures $[34,71,76]$. Briefly, 100,000 cells were plated per $60-\mathrm{mm}$ dish. Dendritic spine number was calculated in individual mature hippocampal neurons obtained from three independent experiments $(n=9$ cells/treatment within one experiment). Neurons were exposed to synthetic Aß42 (200 nM) for $24 \mathrm{~h}$ with or without S107 (1 or $10 \mu \mathrm{M})$. Mature hippocampal neurons were stained with TRITCconjugated phalloidin revealing actin-rich structures along the dendritic shaft [71]. We analyzed a total dendrite length of $40 \mu \mathrm{m}$ per cell. Dendritic spine number and diameter were determined based on the phalloidin staining obtained from a $2 \mathrm{D}$ projection (maximum intensity) of each image stack [75]. The diameter and density of dendritic spines per cell were averaged from each experiment (total population in each experiment). Data from the three experiments were pooled together and plotted.

\section{Statistical analyses}

All experimental mice were coded to blind investigators with respect to genotypes and S107 treatment. MWM and LTP/LTD results were revealed by two-way ANOVA 
and post-test comparisons. Other studies that contained multiple groups were revealed by one-way ANOVA and Bonferroni post-test or Tukey multiple comparison test. Results were expressed as mean \pm SEM. Sample size for each experiment is stated in the figure legends. Minimum statistically significant differences were established at $p<0.05$.

\section{Results}

\section{RyR2 macromolecular complex is remodeled in human Alzheimer's brains and in AD-like murine models}

Neuronal RyR2 channels were examined for evidence of post-translational modifications consistent with the biochemical signature of leaky RyR2 channels [51, 52]. Neuronal RyR2 from age-matched "control" brains (diagnosed as negative for any neuropathology) (suppl. Table I) had no biochemical remodeling of the RyR2 macromolecular complex, while the age-matched "non-AD" brains (negative for any AD-related neuropathology, i.e., absence of neurofibrillary tangles and neuritic plaques) (suppl. Table I) exhibited nitrosylation and oxidation of RyR2 with partial calstabin2 depletion, but no PKA phosphorylation. Only the AD patients (suppl. Table I) exhibited RyR2 PKA hyperphosphorylation (at Ser2808), in addition to oxidation (DNP), nitrosylation (Cys NO) and nearly complete channel stabilizing subunit calstabin2 (FKBP12.6) depletion (Fig. 1a-e). Intriguingly, RyR2 macromolecular complexes from the AD patients also showed reduced serine/threonine protein phosphatase 1 (PP1) $[51,52]$ and reduced anchoring protein spinophilin [51] (Fig. 1a, f, g). PKA, PDE4 and PP2A expression remained unchanged in $\mathrm{AD}$ brains as compared to controls and non-AD brains (Fig. 1a, and Suppl. Figure 1a-c). RyR2 channels were PKA phosphorylated, oxidized, nitrosylated and depleted of calstabin2 in both the double transgenic AD mouse model $\left(A P P^{+/-} / P S 1^{+/-}\right)$ (APPswe, PS1-M146V) [22, 38] (Fig. 1h-1) and the triple transgenic $\mathrm{AD}$ mouse model $(3 \times \mathrm{Tg}-\mathrm{AD}:$ APPswe, PS1$M 146 \mathrm{~V}$, and Tau-P301L) [57] (Fig. 10-s). In these AD-like mice models, PP1 and spinophilin were also depleted from the RyR2 macromolecular complex (Fig. 1h, m-o, t, u), while PKA, PDE4 and PP2A levels remained unchanged (Fig. 1h, o and Suppl. Figure 1d-i). We used the RyR-targeted small molecule Rycal S107 that stabilizes binding of calstabin to RyR2 and thereby stabilizes the closed states of PKA phosphorylated and oxidized/nitrosylated channels by preventing calstabin2 depletion $[51,52]$. Administration of S107 to $A P P^{+/-} / P S 1^{+/-}$and $3 \times$ Tg-AD mice had no effect on PKA hyperphosphorylation or oxidation/nitrosylation of RyR2, but significantly increased the amount of calstabin2 in the RyR2 channel complex (Fig. 1h, l, o, s). RyR2 channels from 3-month-old $A P P^{+/-} / P S 1^{+/-}$mice crossed with the RyR2-S2808A $A^{+/+}$knock-in mice, harboring RyR2 channels that cannot be PKA phosphorylated [48], did not undergo phosphorylation but exhibited reduced oxidation and nitrosylation and there was no evidence of calstabin2 depletion from the RyR2 complex (Fig. 1h-1).

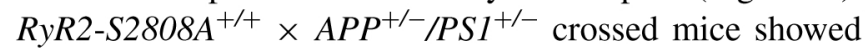
increased amounts of PP1 and spinophilin in the channel complex as compared to $A P P^{+/-} / P S 1^{+/-}$mice (Fig. $1 \mathrm{~h}, \mathrm{~m}$, n).

There were no changes in total RyR2 or calstabin2 levels in the whole brain lysates from all experimental animals as previously reported [48]. S107 does not affect the levels of RyR2 or calstabin2 in WT mice. The remodeling of RyR2 observed in the brains of AD patients and of ADlike mice models represents the "biochemical signature" of leaky channels.

RyR2 is PKA phosphorylated through the activation of the $\beta$-adrenergic receptor $(\beta$-AR) signaling cascade [51, 52]. Interestingly, PKA activity was increased in $A P P^{+/-}$, $\mathrm{PSI}^{+/-}$(Suppl. Figure 2a), suggesting the contribution of $\beta$-adrenergic signaling cascade in these mice. Mitochondrial ROS production was also enhanced in $\mathrm{APP}^{+/-}$/ $\mathrm{PSI}^{+/-}$mice and inhibited by $\mathrm{S} 107$ or by crossing $A P P^{+/-}$/

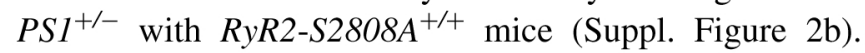
Taken together, these data suggest that RyR2 remodeling is likely triggered by synergistic oxidative and $\beta$-adrenergic stimulation.

\section{Remodeling of neuronal RyR2 channel complexes results in abnormal $\mathrm{Ca}^{2+}$ homeostasis}

We then asked whether the remodeling of neuronal RyR2 channel complexes results in abnormal $\mathrm{Ca}^{2+}$ homeostasis. Neuronal microsomes from $A P P^{+/-} / P S 1^{+/-}$mice exhibited increased $\mathrm{ER} \mathrm{Ca}^{2+}$ leak compared to WT mice (Fig. 2a, b). Pharmacologically stabilizing calstabin 2 on RyR2 complex by administering $\mathrm{S} 107$ or genetically crossing with $R y R 2$ $S 2808 A^{+/+}$mice significantly reduced neuronal $\mathrm{ER} \mathrm{Ca}^{2+}$ leak in $\mathrm{APP}^{+/-} / \mathrm{PSI}^{+/-}$(Fig. 2a, b). Addition of the specific RyR blocker ryanodine $(10 \mu \mathrm{M})$ after thapsigargin-triggered $\mathrm{Ca}^{2+}$ leak abolished the leak (Suppl. Figure 3a-d), thus confirming the RyR channel as the trigger of the $\mathrm{Ca}^{2+}$ leak. Consistently, hippocampal RyR2 channels from $3 \times$ Tg-AD mice were leaky as manifested by increased single-channel open probabilities (Po) (Fig. 2c, d). Treatment of the $3 \times \mathrm{Tg}-\mathrm{AD}$ mice with the $\mathrm{S} 107$ normalized the channel Po consistent with fixing the leak (Fig. 2c, d). Thus, neuronal RyR2 channel remodeling causes ER Ca ${ }^{2+}$ leak in two AD-like mice models.

Neuronal sarcoplasmic/endoplasmic reticulum $\mathrm{Ca}^{2+}$ ATPase (SERCA) (responsible for pumping $\mathrm{Ca}^{2+}$ into 
Fig. 1 Hippocampal RyR2 channel remodeling resulting in biochemical "signature of leaky channels" in human AD brains and murine models of AD. Representative SDS-PAGE analyses and quantification of hippocampal RyR2 immunoprecipitated from: a-g human brains (see suppl. Table I) "control"

$(n=3)$; age-matched "non-AD" individuals $(n=4)$; and Alzheimer's patients (AD) $(n=6)$; h-n WT, $A P P^{+/-} / P S 1^{+/-}$, $A P P^{+/-} / P S 1^{+/-}+\mathrm{S} 107$ and

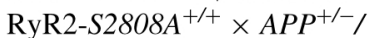
$P S 1^{+/-}$crossed mice $(n=4$ for each group of mice);

o-u WT, $3 \times \mathrm{Tg}-\mathrm{AD}$ and $3 \times \mathrm{Tg}-\mathrm{AD}+\mathrm{S} 107$ mice $(n=5$ for each group of mice) immunoblotted for total RyR2, RyR2pS2808 (RyR2 PKA phosphorylation site), $S$-nitrosylation (CysNO), oxidation (DNP), as well as components of the RyR2 channel complex including: PKA catalytic subunit (PKA), phosphodiesterase 4D3 (PDE4), protein phosphatase 2A (PP2A), protein phosphatase 1 (PP1) and its anchoring protein spinophilin and calstabin2. S107 treatment was from 4 weeks of age until testing at 3 months in $\mathrm{APP}^{+/-} / \mathrm{PS} 1^{+/-}$, and from 11 months of age for 4 weeks in $3 \times$ Tg-AD mice. Graphs represent mean \pm SEM. $* p<0.05$ calculated versus control using one-way ANOVA and Tukey's post-tests

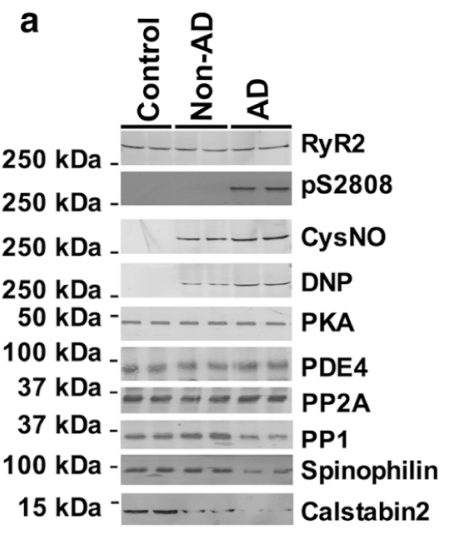

h
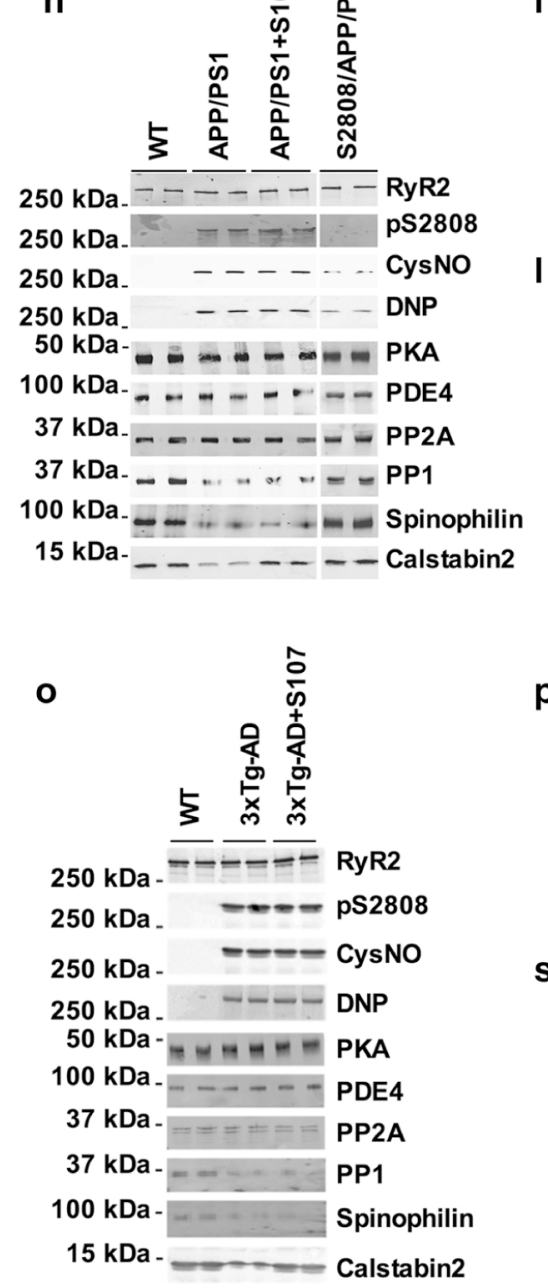

b

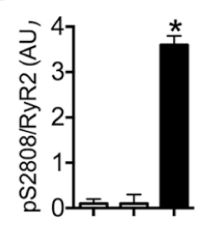

e

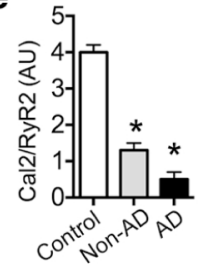

C

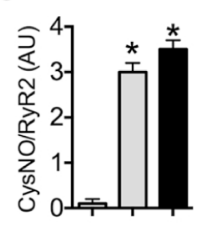

f
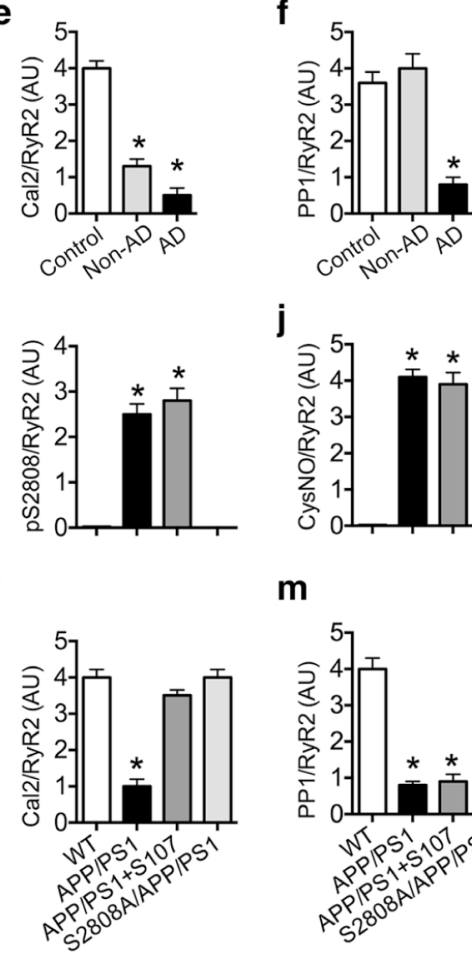

p

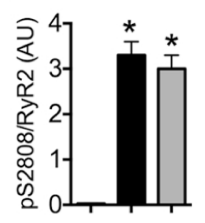

S

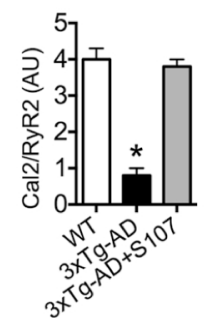

m

q

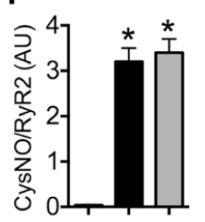

t

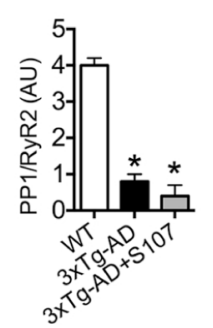

d

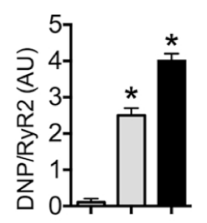

g

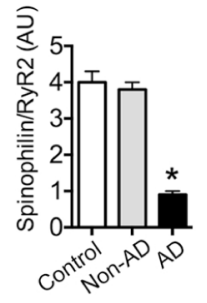

k
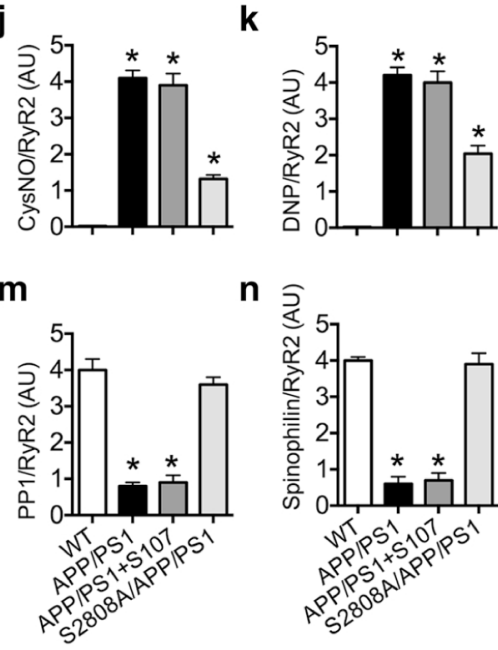

n

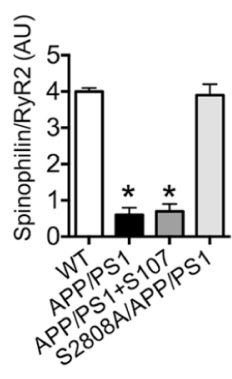

$\mathbf{r}$

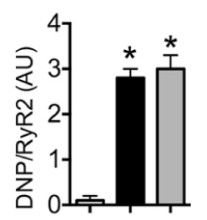

$\mathbf{u}$

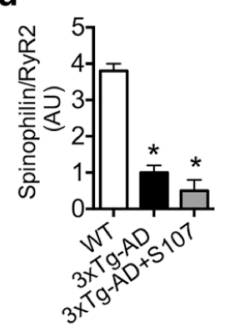

the ER in neurons) activity was increased in $\mathrm{APP}^{+/-} /$ $\mathrm{PSI}^{+/-}$mice compared to WT, but treatment with $\mathrm{S} 107$ did not affect SERCA activity (Suppl. Figure 4a). Caffeine-induced $\mathrm{ER} \mathrm{Ca}^{2+}$ release was increased in $\mathrm{APP}^{+/-}$, $\mathrm{PSI}^{+/-}$mice compared to the control, and $\mathrm{S} 107$ reduced this response (Suppl. Figure $4 \mathrm{~b}-\mathrm{e}$ ). This increased sensitivity of RyR channels to caffeine in the $A P P^{+/-} / P S 1^{+/-}$ mice is likely due to depletion of calstabin2 from the channel complex, which destabilizes the closed state of RyR channels and sensitizes the channel to caffeine [9, 52]. $\mathrm{Ca}^{2+}$ influx through voltage-gated calcium channels (VGCC) was normal in $A P P^{+/-} / P S I^{+/-}$mice and unaffected by S107 treatment (Suppl. Figure 4f-i). Passive and active electrophysiological properties were similar between $A P P^{+/-} / P S 1^{+/-}$and control neurons, and unaffected by S107 treatment (Suppl. Figure 4j). 
a

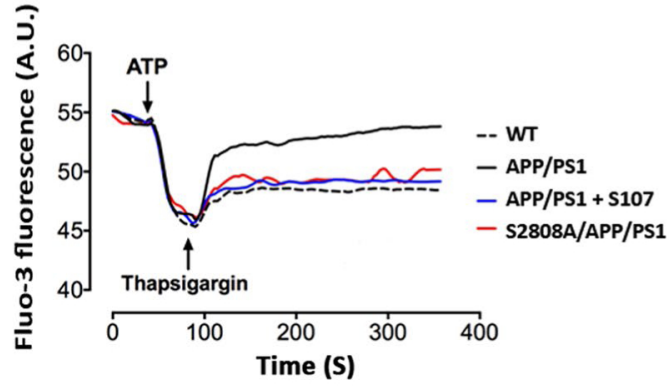

C WT

Po 0.01

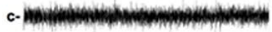

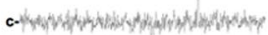

WT+S107

Po 0.01

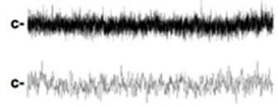

3xTg-AD

Po 0.15

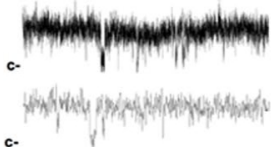

3xTg-AD+S107

Po 0.01

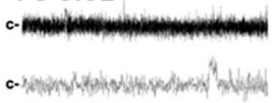

Fig. 2 Remodeling of neuronal RyR2 channel complex results in abnormal $\mathrm{Ca}^{2+}$ homeostasis in $A P P^{+/-} / P S 1^{+/-}$and $3 \times \mathrm{Tg}-\mathrm{AD}$ mice and is reversed by $\mathrm{S} 107$ and genetic rescue with RyR2 $S 2808 A^{+/+}$. a-b Neuronal microsomes from $A P P^{+/-} / P S 1^{+/-}$mice exhibited increased $\mathrm{ER} \mathrm{Ca}^{2+}$ leak $(55 \pm 7 \%$ vs. $21 \pm 4 \%$ in WT mice, $n \geq 5$ for each group). Pharmacologically inhibiting ER $\mathrm{Ca}^{2+}$ leak by administering S107 (as in Fig. 1h-n) and crossing with $R y R 2 S 2808 A^{+/+}$mice reduced neuronal ER $\mathrm{Ca}^{2+}$ leak in $A P P^{+/-}$, $P S 1^{+-}$(22 \pm 4 , and $55 \pm 7 \%, n=7$ for each group). c, d Hip-

Previous studies in FAD mice have shown that RyRmediated $\mathrm{ER} \mathrm{Ca}^{2+}$ release can facilitate glutamatergic spontaneous excitatory postsynaptic potential (sEPSP) activity $[8,11,35] . A P P^{+/-} / P S 1^{+/-}$CA1 pyramidal neurons exhibited significantly increased sEPSPs frequency compared to WT mice, consistent with intracellular $\mathrm{Ca}^{2+}$ leak in presynaptic terminals in the $A P P^{+/-} / P S 1^{+/-}$mice (Suppl. Figure $4 \mathrm{k}-\mathrm{o}$ ). Treatment with $\mathrm{S} 107$ normalized sEPSP frequency in $A P P^{+/-} / P S 1^{+/-}$mice (Suppl. Figure $4 \mathrm{k}-\mathrm{m}$, and $4 \mathrm{o}$ ), without affecting sEPSP amplitudes (Suppl. Figure $4 \mathrm{k}-\mathrm{m}$, and $4 \mathrm{o}$ ).

\section{Impaired RyR2 function affects cognitive behavior in AD-like mice models}

We next sought to determine whether leaky hippocampal RyR2 channels modulate the encoding or retrieval of contextual fear memories. In the contextual fear conditioning (FC) test, 3-month-old $A P P^{+/-} / P S 1^{+/-}$mice exhibited decreased freezing compared to the WT mice (Fig. 3a). This was improved when RyR2-mediated intracellular $\mathrm{Ca}^{2+}$ leak was inhibited either pharmacologically

b

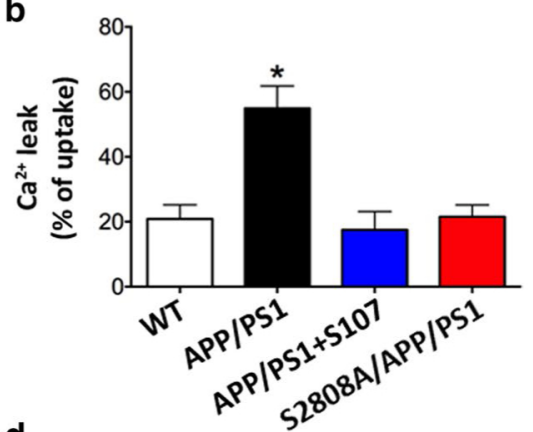

d

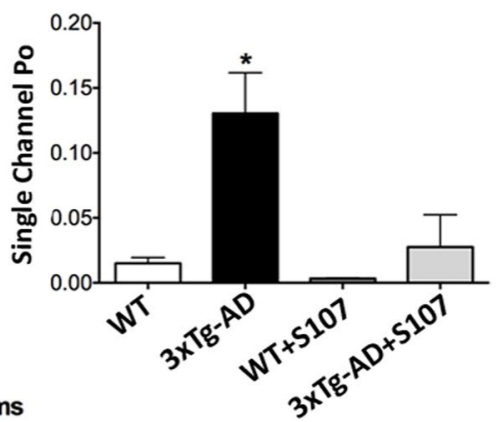

pocampal RyR2 channels of $3 \times \mathrm{Tg}$-AD mice were leaky as manifested by increased single-channel open probabilities $(\mathrm{Po})$ under resting conditions (e.g., with low cytosolic activating $\left[\mathrm{Ca}^{2+}\right]_{c}$, control $\mathrm{Po}=0.0145 \pm 0.0044, n=5$ vs. $3 \times \mathrm{Tg}-\mathrm{AD}$ Po $=0.1304 \pm 0.0313$, $n=6$ ). Treatment of the $3 \times \mathrm{Tg}-\mathrm{AD}$ mice with the $\mathrm{S} 107$ (as in Fig. 1o-u) normalized the channel Po $(\mathrm{Po}=0.0275 \pm 0.0249, n=6)$ consistent with fixing the leak. Data are mean \pm SEM. *, $p<0.05$ versus WT. Data were analyzed using the one-way ANOVA and Tukey's post-test

with $\mathrm{S} 107$ treatment of $A P P^{+/-} / P S 1^{+/-}$mice, or genetically in RyR2-S2808A ${ }^{+/+} \times A P P^{+/-} / P S 1^{+/-}$crossed mice (Fig. 3a). There was also decreased freezing in auditory cued $\mathrm{FC}$ in $A P P^{+/-} / P S 1^{+/-}$compared to the WT mice (Fig. 3b), which was improved by genetic rescue (crossing $\mathrm{APP}^{+/-} / \mathrm{PS}^{+/-}$mice with RyR2-S2808A mice), but not by $\mathrm{S} 107$ treatment. These data suggest that the intracellular $\mathrm{Ca}^{2+}$ leak via remodeled RyR2 channels may be associated with impaired encoding and retrieval of contextual fear memory.

$\mathrm{APP}^{+/-} / \mathrm{PSI}^{+/-}$mice also exhibited short-term memory deficits as manifested in the novel object recognition (NOR) test by reduced discrimination index (DI) between the novel object and the constant object after $1 \mathrm{~h}$ (Fig. 3c, d). Both pharmacologic treatment with $\mathrm{S} 107$ and genetic rescue improved hippocampal-based short-term memory as evidenced by normalization of the DI (Fig. 3d). These data further suggest that RyR2 $\mathrm{Ca}^{2+}$ leak is associated with impaired short-term memory formation in a murine model of AD.

We assessed the effects of leaky RyR2 channels on spatial learning and memory using the Morris water maze 


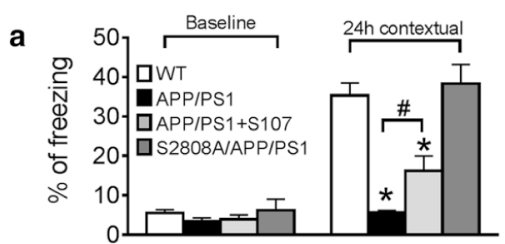

c

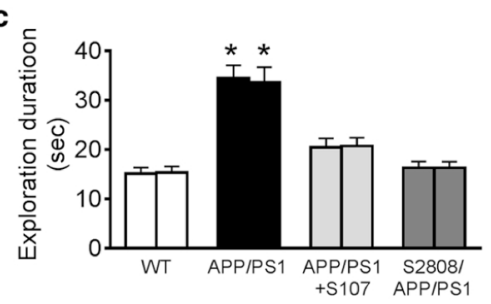

e

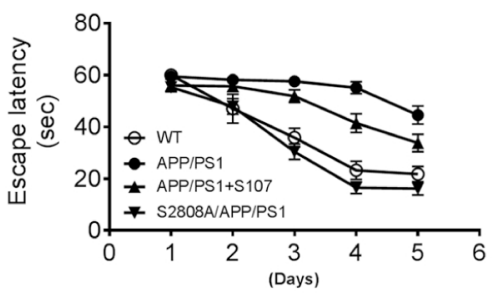

g
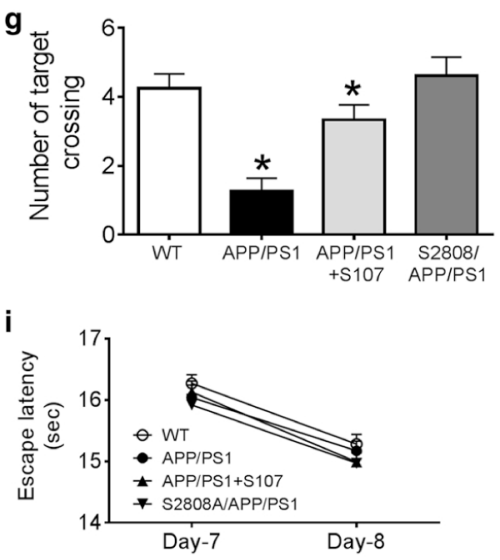

k

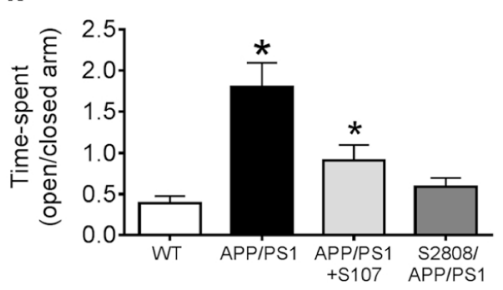

Fig. 3 S107 treatmentor genetic rescue targeting leaky RyR2 channels improves cognitive function in $\mathrm{AD}$. Freezing responses in contextual fear conditioning (FC) (a) and auditory cued FC (b). WT, $n=19, A P P^{+/-} / P S 1^{+/-}, n=15, A P P^{+/-} / P S 1^{+/-}+\mathrm{S} 107, n=13$, $R y R 2-S 2808 A^{+/-} \times A P P^{+/-} / P S 1^{+/-}$crossed mice, $n=11$. c The exploration durations for mice in the novel object recognition test (NOR) with two identical objects (T1, T2) during the 5-min exposure period. d After a 1-h interval the exploration durations for mice to the constant object $\left(T_{1}\right)$ and the novel object $\left(T_{\mathrm{N}}\right)$ were recorded during a 2-min exposure period and shown as the discrimination index $\left[\mathrm{DI}=\left(T_{\mathrm{N}}-T_{1}\right) /\left(T_{\mathrm{N}}+T_{1}\right)\right] . \mathrm{WT}, n=20, A P P^{+/-} / P S 1^{+/-}, n=15$, $A P P^{+/-} / P S 1^{+/-}+\mathrm{S} 107, n=18, R y R 2-S 2808 A^{+/-} \times A P P^{+/-} / P S 1^{+/-}$, $n=11$. e Learning curves showing the escape latency during a 5-day training period in the Morris water maze (MWM). f, $\mathbf{g}$ The time spent

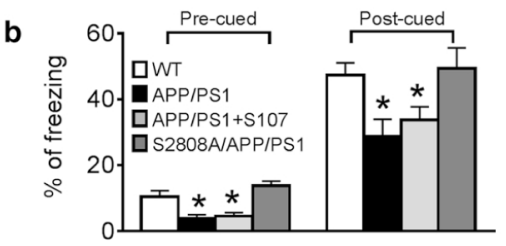

d
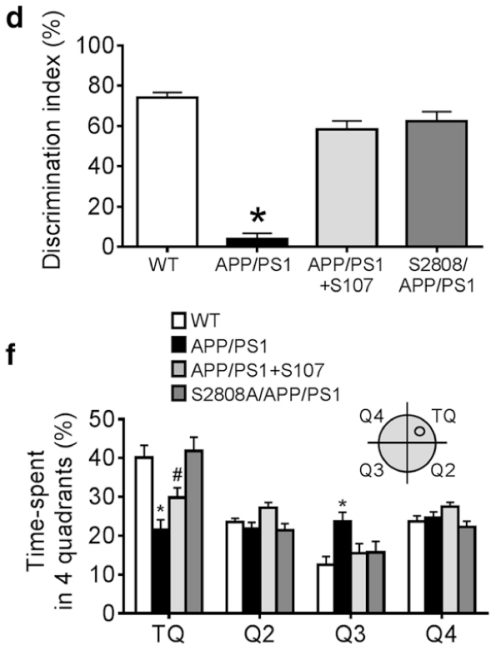

h
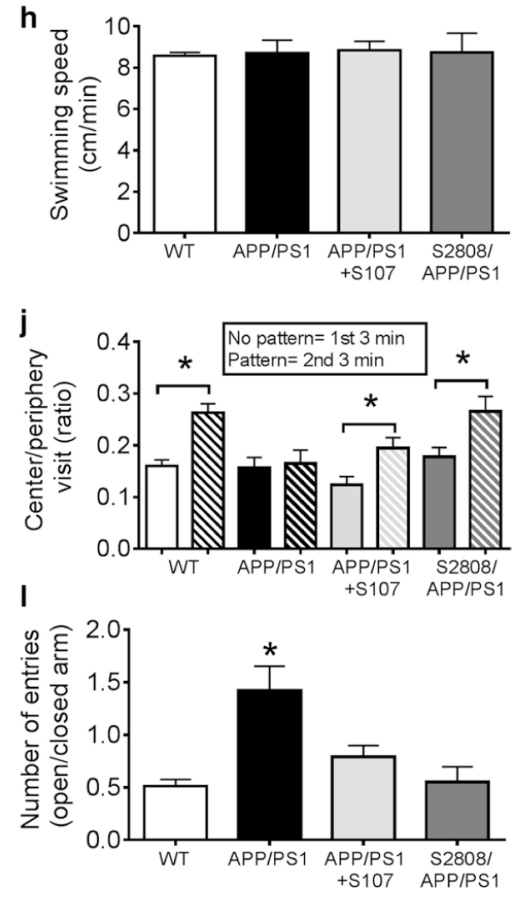

in all quadrants and the number of target crossings on day 6 probe trial of the MWM. h Swimming speeds were recorded on day 6 probe trial. i Escape latencies for the visible platform test was performed for 2 days after day 6 of the probe trial, 3 trials per day, $60 \mathrm{~s}$ for each trial. j Ratio of the center vs. periphery visits in the open field test (OF). k Time spent in the open vs. closed arms of the elevated plus maze (EPM) and $\mathbf{I}$ the ratio of the number of entries to the open vs. closed arms. The same groups of mice were used for NOR, MWM, OF and EPM tests. Separate groups of naïve mice were used for FC tests. S107 treatment was from 4 weeks of age until testing at 3 months. Learning curve data from MWM test were analyzed using the two-way ANOVA. All other data were analyzed using the one-way ANOVA and Bonferroni post-test. Graphs show mean $\pm \mathrm{SEM}$, ${ }^{*}, p<0.05$ versus WT mice, $\#, p<0.05$ versus $A P P^{+/-} / P S I^{+/-}$mice 
(MWM). $A P P^{+/-} / P S 1^{+/-}$mice exhibited higher escape latencies in the MWM (Fig. 3e), spent less time in the target quadrant and had a reduced number of target crossings compared to WT mice (Fig. 3f, g). S107 treatment of $A P P^{+/-} / P S I^{+/-}$mice partially improved the escape latency, the time spent in the target quadrant and the number of target crossings compared to untreated $\mathrm{APP}^{+/}$/ $P S 1^{+/-}$mice. Genetic rescue of leaky RyR2 channels using RyR2-S2808A $A^{+/+} \times A P P^{+/-} / P S 1^{+/-}$crossed mice resulted in normalization of escape latencies (Fig. 3e), the time spent in the target quadrant and the number of target crossings (Fig. 3f, g). Similar data were obtained using the $3 \times \mathrm{Tg}$-AD model in the MWM showing that $\mathrm{S} 107$ treatment improved the escape latency (Suppl. Figure 5a). In the probe trials, S107-treated $3 \times \mathrm{Tg}$-AD mice exhibited reduced latency to the first entry into the target quadrant (TQ) and platform (PF) zones (Suppl. Figure 5b, and 5c) and reduced distance to the first entry in the PF zone (Suppl. Figure 5d). Accordingly, S107-treated $3 \times \mathrm{Tg}-\mathrm{AD}$ mice spent more time and showed enhanced number of entries in TQ zone (Suppl. Figure 5e, and 5f). Importantly, the observed deficits in the MWM in both $A P P^{+/-} / \mathrm{PSI}^{+/-}$ and $3 \times \mathrm{Tg}-\mathrm{AD}$ mice models were not due to defects in swimming speed (Fig. 3h, and Suppl. Figure 5 g) or altered vision function (Fig. 3i).

Leaky RyR2 channels were associated with additional behavioral abnormalities including increased anxiety studied by open field $(\mathrm{O}-\mathrm{F})$ and elevated plus maze (EPM) tests. The $A P P^{+/-} / P S 1^{+/-}$mice made an equal number of visits to the center and periphery in the O-F test (Fig. 3j) and spent more time and made more entries into the open arms of the EPM (Fig. 3k, 1), in agreement with disinhibited behavior previously reported in $A P P^{+/-} / P S 1^{+/-}$mice [40]. This behavior was restored to normal by both pharmacologic treatment with $\mathrm{S} 107$ and genetic rescue with RyR2-S2808A ${ }^{+/+} \times A P P^{+/-} / P S 1^{+/-}$crossed mice (Fig. 3j1). Additionally, $A P P^{+/-} / P S 1^{+/-}$mice exhibited increased spontaneous exploratory behavior that was not seen in mice treated with $\mathrm{S} 107$ or in $R y R 2-S 2808 A^{+/+} \times A P P^{+/-} / P S 1^{+/-}$ crossed mice in the NOR, OF and EPM tests (Fig. 3c, j, k).

\section{RyR2 leak impairs postsynaptic function in hippocampal neurons}

As part of the " $\mathrm{Ca}^{2+}$ hypothesis" of $\mathrm{AD}$, it has been proposed that a combination of progressive reduction in longterm synaptic potentiation (LTP) and increase in long-term synaptic depression (LTD) may contribute to memory loss $[6,25,55]$. CA3-CA1 Schaffer collateral LTP was reduced in 3-month-old $A P P^{+/-} / P S 1^{+/-}$mice compared to WT (Fig. 4a) with no differences in basal synaptic transmission (BST) (Fig. 4c). Both pharmacologic treatment with $\mathrm{S} 107$ and genetic rescue in $R y R 2-S 2808 A^{+/+} \times A P P^{+/-} /$
$P S 1^{+/-}$crossed mice significantly improved the LTP in the $A P P^{+/-} / P S 1^{+/-}$mice (Fig. 4a). LTD was also reduced in 3-month-old $A P P^{+/-} / P S 1^{+/-}$mice compared to WT and restored to the WT levels by treatment with $\mathrm{S} 107$ or with genetic rescue (Fig. 4b). LTP and LTD were also reduced in 6-month-old $A P P^{+/-} / P S 1^{+/-}$mice with reduced BST as well (Fig. 4d-f). Treatment with S107 improved both LTP and LTD at 6 months of age (Fig. 4d-f). S107 treatment had no effect on LTP, LTD or BST in WT mice (Suppl. Figure $6 \mathrm{c}-\mathrm{e}$ ). These data suggest that both defective memory formation (LTP) and impaired editing (LTD) contribute to cognitive and behavioral abnormalities observed in $A P P^{+/-} / P S 1^{+/-}$mice that are rescued by pharmacologic or genetic targeting of RyR2 leak.

Loss of postsynaptic dendritic spines contributes to memory and cognitive deficits in $\mathrm{AD}[53,75,76]$. We examined the possible effects of leaky RyR2 channels on dendritic spine morphology by treating primary cultured hippocampal neurons with $\mathrm{S} 107$ in the presence of A 342 peptides. The spine diameter was significantly decreased $24 \mathrm{~h}$ after the addition of A 342 peptides (200 nM) (Fig. $4 \mathrm{~g}$ ). Pretreatment with $\mathrm{S} 107$ prevented dendritic spine collapse (Fig. 4g).

\section{Leaky RyR2 channels contribute to neuropathology in transgenic AD-like mice}

Next, we determined whether inhibiting leaky RyR2 affects $\mathrm{A} \beta$ plaque deposition in brain slices in 5-monthold $\mathrm{APP}^{+/-} / \mathrm{PSI}^{+/-}$mice. Both $\mathrm{S} 107$ treatment (beginning at 3 months of age) and genetic rescue with $R y R 2$ $S 2808 A^{+/+} \times \mathrm{APP}^{+/-} / \mathrm{PS1^{+/- }}$ crossed mice reduced the number of $A \beta$ plaques (Fig. 5a-e). Accordingly, treatment of $3 \times \mathrm{Tg}-\mathrm{AD}$ mice at 11 months of age (a point at which $\mathrm{A} \beta$ plaques begin to be detectable in this model) with $\mathrm{S} 107$ for 4 weeks also reduced the number and size of $A \beta$ plaques (Fig. 5f-j). GFAP staining revealed increased astrogliosis in the hippocampal CA1 area in $A P P^{+/-} / P S 1^{+/-}$brain slices that was also reduced by $\mathrm{S} 107$ treatment and genetic rescue in $R y R 2-S 2808 A^{+/+} \times \mathrm{APP}^{+/-} / \mathrm{PSI}^{+/-}$crossed mice (Suppl. Figure $7 \mathrm{a}-\mathrm{h}$ ). The total APP was increased in the hippocampus of the $3 \times \mathrm{Tg}$-AD mouse model (due to $\beta$ APP transgene overexpression) (Fig. 5k, 1). Interestingly, the levels of C83 and C99 ( $\alpha-\mathrm{CTF}$ and $\beta$-CTF, respectively), two fragments resulting from $\beta$ APP cleavage by $\alpha$-secretase and $\beta$-secretase (BACE1), were reduced by S107 treatment (Fig. 5k, 1).

We previously reported that $3 \times \mathrm{Tg}-\mathrm{AD}$ mice show a concomitant accumulation of both C99 and C83 and that increased C83 levels derived from $\alpha$-secretase mediated the cleavage of C99 [27, 41, 58]. Therefore, the reduced production of $\mathrm{C} 83$ observed in S107-treated animals could likely be accounted for by reduced levels of its precursor 

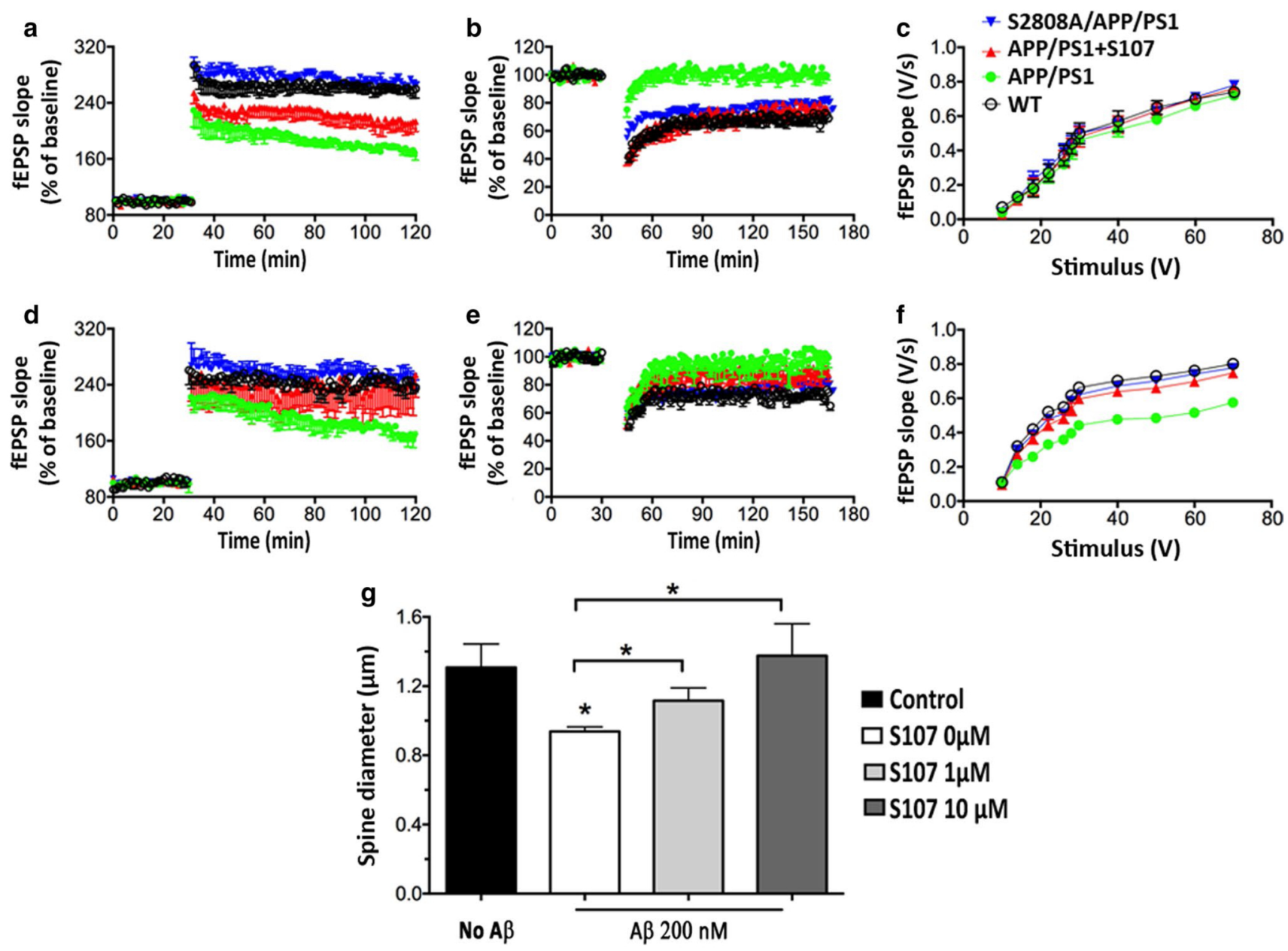

Fig. 4 S107 treatment or genetic rescue targeting leaky RyR2 channels improve hippocampal postsynaptic function and plasticity in AD. S107 treatment, and genetic rescue improved the hippocampal LTP and LTD in 3 months old AD mice (a-c), and 6 months old AD mice (d-f). Electrophysiological recordings were performed by stimulating Schaeffer collateral fibers and recording in the CA1 stratum radiatum. a, d LTP responses were recorded for $90 \mathrm{~min}$ after tetanus. $p<0.05$ for $A P P^{+/-} / P S 1^{+/-}$vs. WT, $A P P^{+/-} / P S 1^{+/-}+\mathrm{S} 107$ and $S 2808 A^{+/-} \mathrm{x} A P P^{+/-} / P S 1^{+/-}$. b, e LTD responses were recorded for $120 \mathrm{~min}$ after low-frequency stimulation (LFS). $p<0.05$ for $A P P^{+/-} /$ $P S 1^{+/-}$versus WT and $A P P^{+/-} / P S 1^{+/-}+$S107. Basal response traces before $\theta$-burst ( 3 tetanus at $100 \mathrm{~Hz}$ in $60 \mathrm{~s}$ ) and a 900-pulse LFS at $1 \mathrm{~Hz}$ for $15 \mathrm{~min}$ are shown. c, $\mathbf{f}$ Input-output curves in the

C99. C99 also undergoes cleavage by $\gamma$-secretase to yield $A \beta 40$ and $A \beta 42$ peptides. The total amounts of soluble and insoluble $A \beta 40$ and $A \beta 42$ were significantly reduced by $\mathrm{S} 107$ treatment in both $3 \times \mathrm{Tg}-\mathrm{AD}$ and $A P P^{+/-} / P S 1^{+/-}$ mice (Fig. 5k, m, n) and in RyR2-S2808A $A^{+/+} \times A P P^{+/-}$, $P S 1^{+/-}$crossed mice (Fig. 5n). These findings were further confirmed in $3 \times$ Tg-AD mice by immunohistochemistry using anti-C-terminus antibodies that specifically recognize $\alpha$-CTF and $\beta$-CTF (Suppl. Figure 7i-k), or with FCA18 antibody [4] that interacts specifically with the $\mathrm{N}$-terminal
CA1 region of hippocampal slices from 3- and 6-month-old mice. WT, 11 slices from six animals; $A P P^{+/-} / P S 1^{+/-}, 10$ slices from five animals; $A P P^{+/-} / P S 1^{+/-}+\mathrm{S} 107,11$ slices from six animals; $R y R 2$ $S 2808 A^{+/-} / \mathrm{APP}^{+/-} / \mathrm{PS1}^{+/-}, 11$ slices from six animals. Data were analyzed by two-way ANOVA. S107 treatment was from 4 weeks of age until age of testing ( 3 or 6 months). $g$ Spine diameter was measured in cultured murine hippocampal neurons. Exposure to $\mathrm{A} \beta 42(200 \mathrm{nM})$ for $24 \mathrm{~h}$ reduced spine diameter and treatment with S107 prevented the reduction in spine diameter. Data were analyzed using the one-way ANOVA and Bonferroni post-test, Graph shows mean $\pm \mathrm{SEM} *, p<0.05$ vs. control (no $\mathrm{A} \beta$ ), or vs. $\mathrm{A} \beta$ treated neurons

aspartyl residue common in both the $\mathrm{A} \beta$ and C99 fragments (Suppl. Figure 7i-n).

BACE1 is highly expressed in neurons and its expression increases during aging as well as in the brains of $\mathrm{AD}$ patients [88]. It was also reported that there is a positive correlation between elevated BACE1 activity, increased A $\beta$ levels and plaque load in mouse and human brain regions $[45,88]$. Accordingly, we showed that BACE1 and $\beta C T F$ levels were increased in human AD brains (Suppl. Figure 8a) and in $A P P^{+/-} / P S 1^{+/-}$brains (Suppl. Figure 8b). 

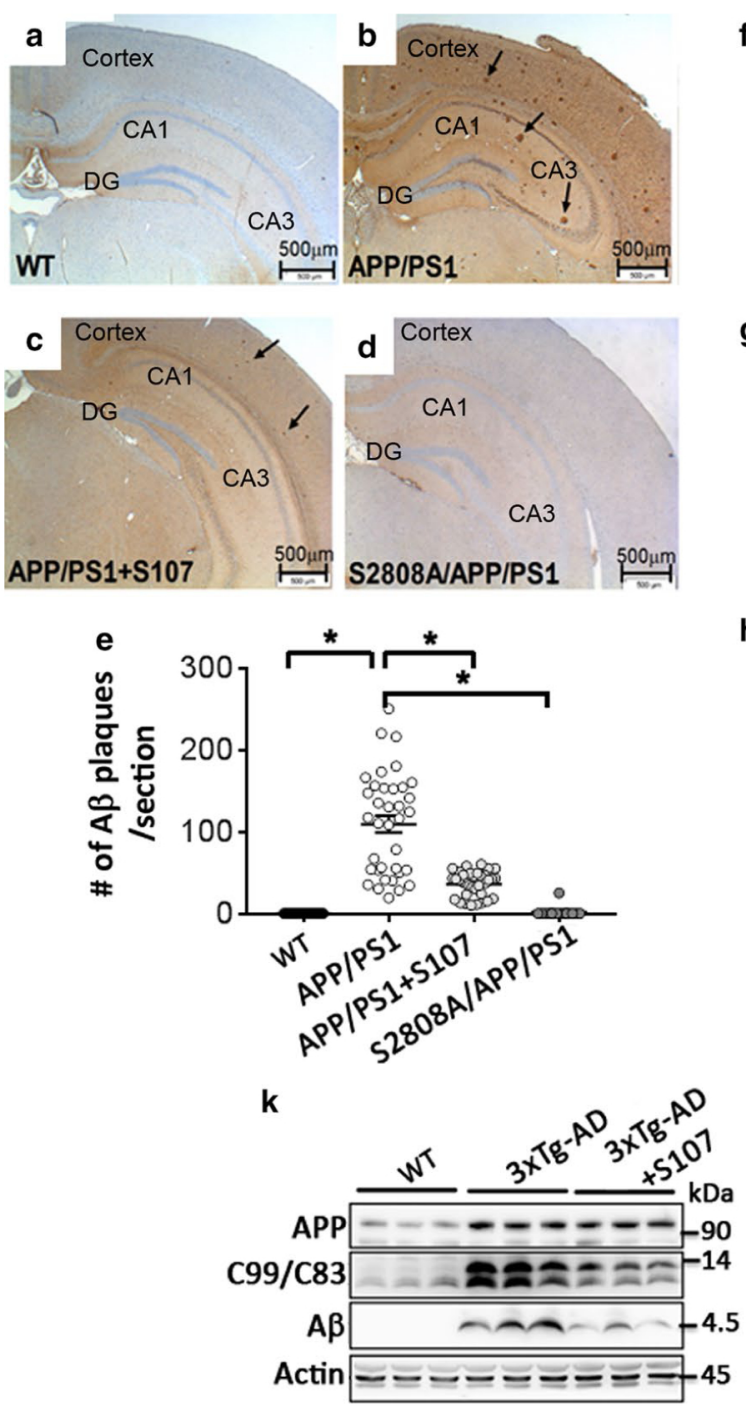

m

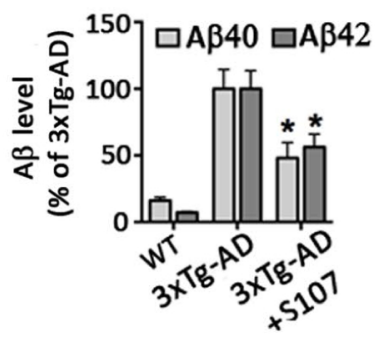

Fig. 5 S107 treatment or genetic rescue targeting of leaky RyR2 channels reduces $A \beta$ production and deposition in AD-like mice brains. Amyloid $\beta$ plaque depositions (arrows) in hippocampal and cortical areas of: a WT mice, b $A P P^{+/-} / P S 1^{+/-}$mice ( 5 month-old), c $A P P^{+/-} / P S 1^{+/-}$mice treated with $\mathrm{S} 107$ beginning at 4 weeks for 4 months (testing at 5 months old), and d $R y R 2$ $S 2808 A^{+/+} \times A P P^{+/-} / P S 1^{+/-}$crossed mice. e Summary data of the number of plaques (mean \pm SEM). Data were taken from six slices per mouse, three mice per group. ${ }^{*}, p<0.05$ vs. WT mice, or vs. APP/PS1 mice. f-h Amyloid $\beta$ plaque depositions (Green signal) in WT (f), $3 \times$ Tg-AD mice (11 months old) treated (h) or not (g) for 4 weeks with S107 (testing at 12 months). Data were taken from four slices per mouse, three mice per group. i, j Graphs show mean \pm SEM of the number (i) and area $(\mathbf{j})$ of $A \beta$ plaques *, f
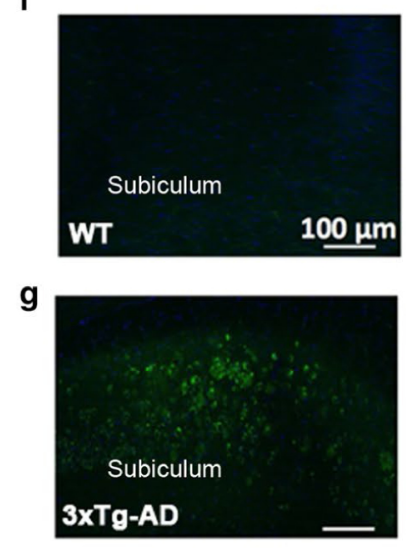

$\mathbf{h}$

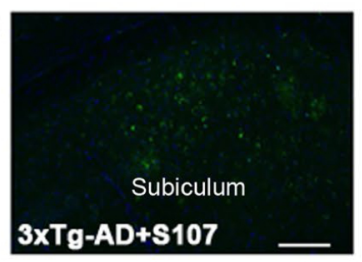

i
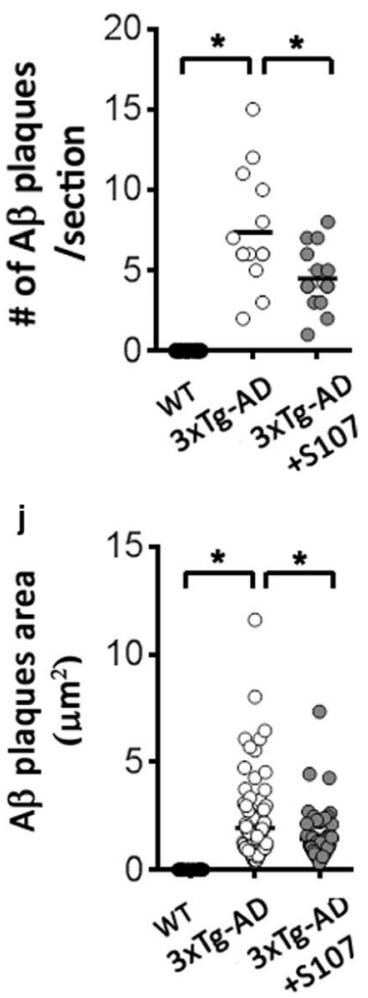
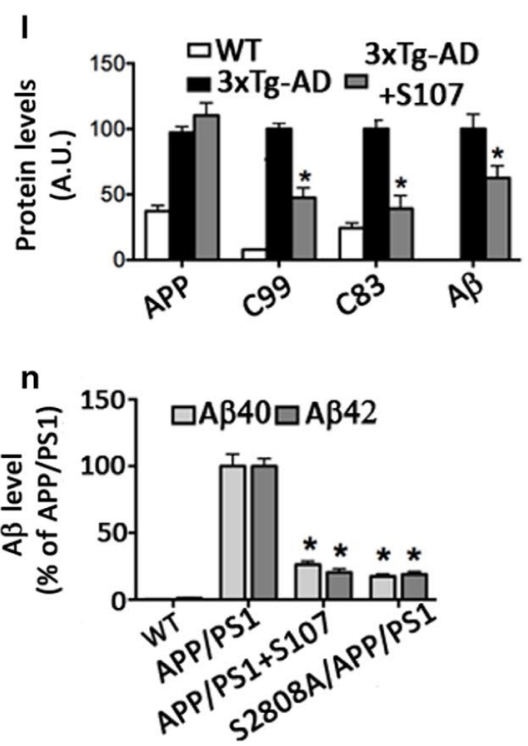

$p<0.05$ vs. WT mice, or vs. $3 \times \mathrm{Tg}$-AD mice. $\mathbf{k}$ Representative blots showing the expression of full length $\beta$ APP, C83 ( $\alpha-\mathrm{CTF})$ and C99 ( $\beta$-CTF), and A $\beta$ in the hippocampus of WT, $3 \times \mathrm{Tg}-\mathrm{AD}$ and $3 \times \mathrm{Tg}-\mathrm{AD}+\mathrm{S} 107$ mice. Data were taken from $>6$ animals per group. $\mathbf{I}$ The graph shows mean \pm SEM of protein levels calculated versus $3 \times$ Tg-AD mice considered as $100 \%$. *, $p<0.05$ versus $3 \times$ Tg-AD mice. $\mathbf{m}, \mathbf{n}$ Soluble and insoluble A $\beta 40$ and A $\beta 42$ levels (detected in total brain lysates (in APP/PS1), or in total hippocampal $(3 \times \mathrm{Tg}-\mathrm{AD})$ lysates). Data were taken from $>4$ animals per group. Graphs show mean $\pm \mathrm{SEM} *, p<0.05$ versus $A P P^{+/-} / P S 1^{+/-}$mice, or versus $3 \times \mathrm{Tg}-\mathrm{AD}$ mice. All data were analyzed using the one-way ANOVA and Tukey's post-test. Representative marker brain structures names are depicted in $(\mathbf{a}-\mathbf{d}$, and $\mathbf{f}-\mathbf{h})$ 
S107 treatment of $A P P^{+/-} / P S 1^{+/-}$mice and genetic rescue with $R y R 2-S 2808 A^{+/+} \times A P P^{+/-} / P S 1^{+/-}$crossed mice normalized BACE1 and $\beta$-CTF levels in $A P P^{+/-} / P S 1^{+/-}$ brains (Suppl. Figure 8b).

We also examined the consequences of inhibiting RyR2mediated $\mathrm{ER} \mathrm{Ca}^{2+}$ leak on the regulation of additional signaling proteins that have been implicated in AD (Suppl. Figure 8). In addition to BACE1 and $\beta C T F, p A M P K, ~ C d k 5$ truncated activator $\mathrm{p} 25$, phosphorylated tau (pT181, pS262) and SAPP $\beta$ were increased in human AD brains (Suppl. Figure $8 \mathrm{a}$ ) as well as in $A P P^{+/-} / P S 1^{+/-}$brains (Suppl. Figure $8 \mathrm{~b}$ ). S107 treatment and genetic rescue returned the levels of these signaling proteins to normal (Suppl. Figure 8b). The formation of neurofibrillary tangles is reported to be downstream of the $\mathrm{Ca}^{2+}$-dependent protease calpain [69]. Tissue calpain activity was increased $\sim$ sixfold compared to WT mice in $A P P^{+/-} / P S 1^{+/-}$brains (Suppl. Figure 8c) and was reduced by both $\mathrm{S} 107$ treatment and genetic res-

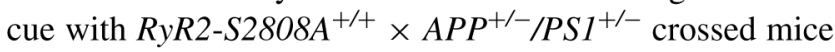
(Suppl. Figure 8c).

\section{Constitutive RyR2 phosphorylation induces synaptic and cognitive deficits}

We then explored the importance of RyR2 PKA phosphorylation and leak in synaptic and cognitive deficits in a genetic background free of any AD-associated mutations using a PKA phosphomimetic knock-in mouse model $\left(R y R 2-S 2808 D^{+/+}\right)$[48, 72]. At 3 months of age, hippocampal RyR2 channels from $R y R 2-S 2808 D^{+/+}$mice were oxidized, nitrosylated and depleted of calstabin2 (Fig. 6a). S107 treatment prevented calstabin2 depletion from hippocampal RyR2 channels (Fig. 6a), but had no effect on channel oxidation and nitrosylation in RyR2$S 2808 D^{+/+}$mice. Neuronal microsomes isolated from RyR2-S2808D ${ }^{+/+}$mice brain exhibited increased ER Ca ${ }^{2+}$ leak compared to those from WT mice (Suppl. Figure 9a, 9b). Administration of $\mathrm{S} 107$ significantly reduced neuronal ER Ca ${ }^{2+}$ leak in RyR2-S2808D ${ }^{+/+}$mice (Suppl. Figure 9a, $9 b)$. Adding ryanodine confirmed that the source of $\mathrm{Ca}^{2+}$ release was mainly associated with RyR channels (Suppl. Figure 3e, 3f). Thus, phosphomimetic neuronal RyR2 channels in $R y R 2-S 2808 D^{+/+}$mice cause an $\mathrm{ER} \mathrm{Ca}^{2+}$ leak.

$R y R 2-S 2808 D^{+/+}$mice exhibited also cognitive and behavioral dysfunctions as assessed by contextual and cued FC (Fig. 6b, c), MWM (Fig. 6d-f), NOR (Fig. 6j), and EPM tests (Fig. 6k, 1), without differences in swimming or latency to find a visible platform (Fig. $6 \mathrm{~g}$, h). Accordingly, LTP and LTD were reduced and synaptic strength was decreased in 3-month-old $R y R 2-S 2808 D^{+/+}$mice (Fig. $6 \mathrm{~m}-\mathrm{o}$ ), consistent with a reduction in dendritic spine density in the hippocampal neurons in $R y R 2-S 2808 D^{+/+}$ mice and a decrease in postsynaptic density protein-95 (PSD95) expression [64, 80] (Fig. 6p, q). S107 treatment of $R y R 2-S 2808 D^{+/+}$mice beginning at 4 weeks of age until testing at 3 months of age (S2808D + S107 (F0)) failed to improve learning and memory deficits (Fig. 6b-1). Interestingly, continuous oral $\mathrm{S} 107$ treatment for two generations (F2) improved cognitive deficits (Fig. 6b-1) and restored LTP, LTD and BST of RyR2-S2808D $D^{+/+}$in 3-month-old mice (Fig. $6 \mathrm{~m}-0$ ). Normalization of these defects by fixing leaky RyR2 with S107 over two generations suggests an epigenetic effect, some of which has been reported in $\mathrm{AD}$ [29]. Interestingly, we found that methylation of hippocampal DNA was increased in $R y R 2-S 2808 D^{+/+}$mice compared to WT mice. S107 treatment decreased DNA methylation in the F2 generation, but not in F0 or F1 generations (Suppl. Figure 10). These data suggest that chronic RyR-mediated ER $\mathrm{Ca}^{2+}$ leak may exert an epigenetic effect regulating gene expression associated with cognitive deficits and synaptic alteration.

\section{Discussion}

It has been proposed that defects in $\mathrm{Ca}^{2+}$ signaling could account for many aspects of AD including memory loss [6], and $\mathrm{Ca}^{2+}$ channels have been recognized as triggering cell survival or death [50]. Indeed, genes encoding $\mathrm{Ca}^{2+}$ handling proteins have recently been linked to $\mathrm{AD}$ in human genome studies [36]. Altered $\mathrm{Ca}^{2+}$ regulation has been reported in both sporadic forms of $\mathrm{AD}$, and FAD linked to $\beta A P P$ and PS1/2 mutations [13, 58]. Moreover, alterations of the expression and function of RyR channels have been reported in human brains and AD models [14, 77, 78]. Several studies have showed that PS mutations induce exacerbated $\mathrm{IP}_{3} \mathrm{R}$ - and RyR-mediated $\mathrm{Ca}^{2+}$ release $[15,24,44$, 77, 78]. It was proposed that the enhanced RyR-mediated $\mathrm{ER} \mathrm{Ca}^{2+}$ release is likely associated with impairment of PS-mediated $\mathrm{Ca}^{2+}$ leak function and to increased $\mathrm{ER} \mathrm{Ca}^{2+}$ pool [92]. However, experiments using the PS1/2 conditional double knockout mice lead to controversial conclusions [87, 92]. Importantly, the impact of $A \beta$ and of $\beta$ APP overexpression on RyR dysfunction was revealed independently of PS mutation or overexpression [43, 56, 58, 79]. Of most interest, it was also reported that exogenous $A \beta$ oligomers may stimulate RyR-mediated $\mathrm{Ca}^{2+}$ release in wild-type hippocampal neurons [61].

We show now that the "biochemical signature" of leaky RyR2 channels is present in the brains of patients with sporadic $A D$ as well as in two murine models harboring FADrelated mutations, suggesting that leaky RyR2 channels may be relevant to both familial and sporadic forms of $\mathrm{AD}$. 


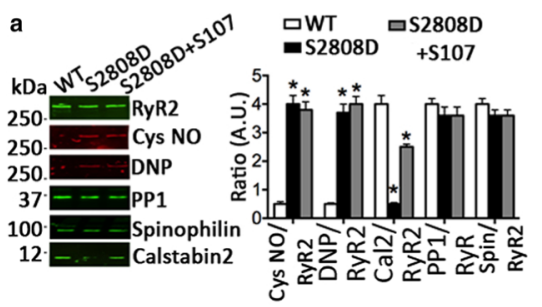

d
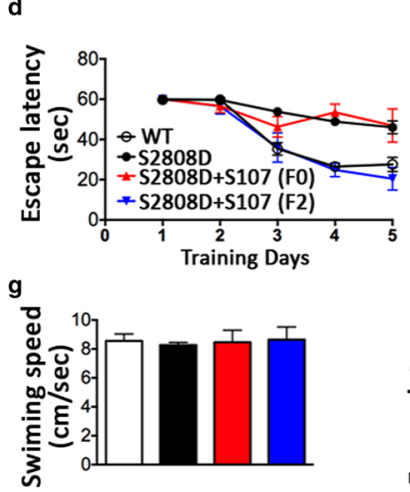

j
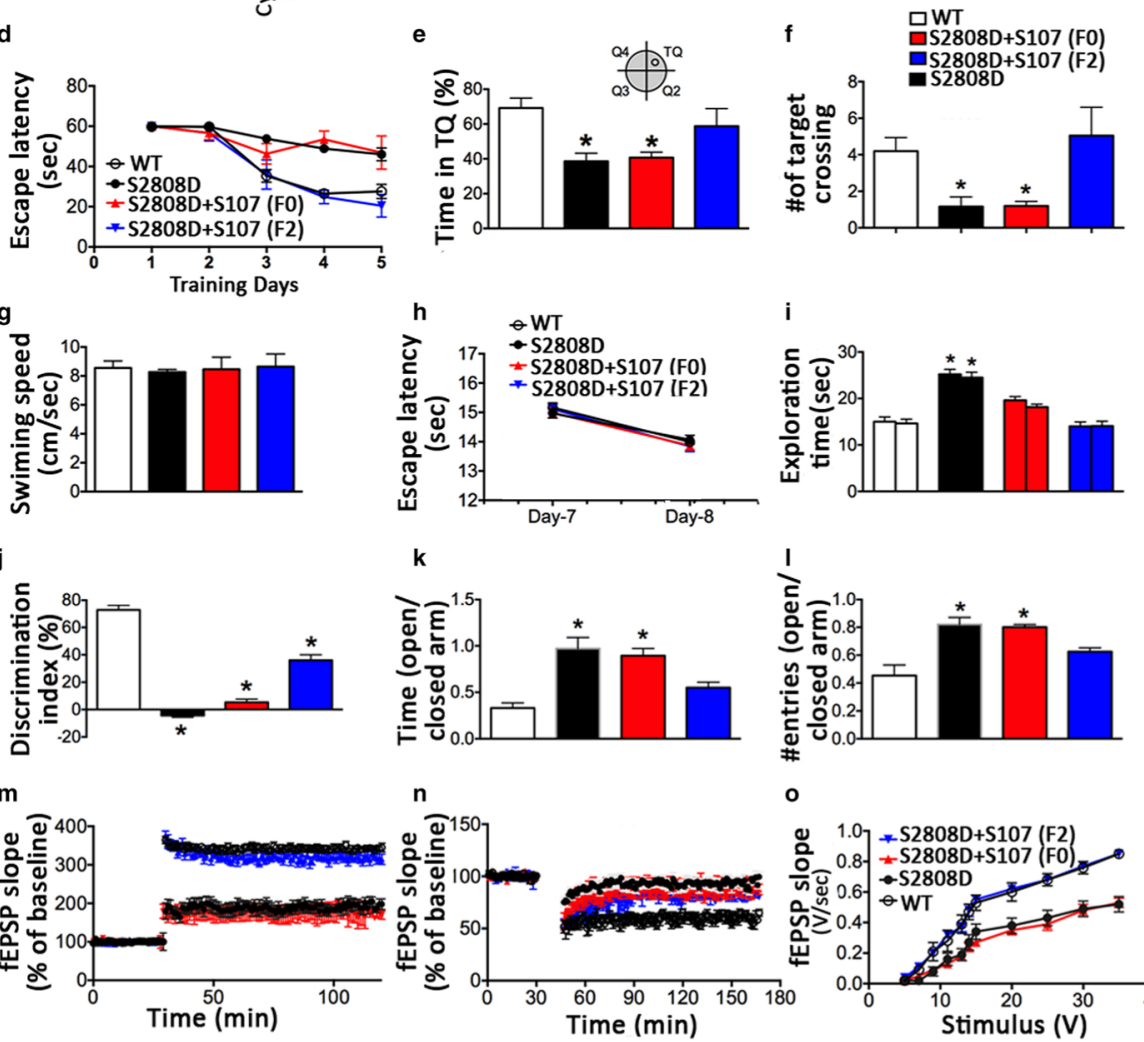

\section{o}
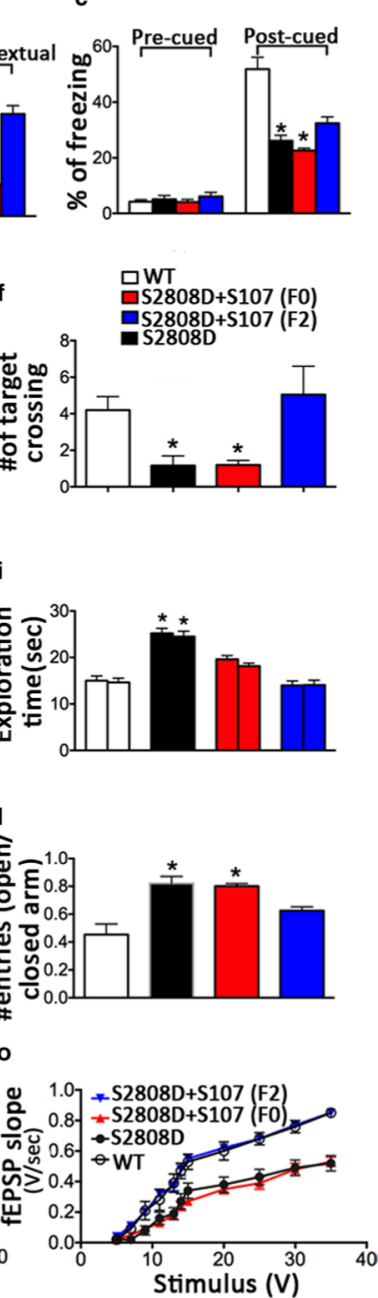

p
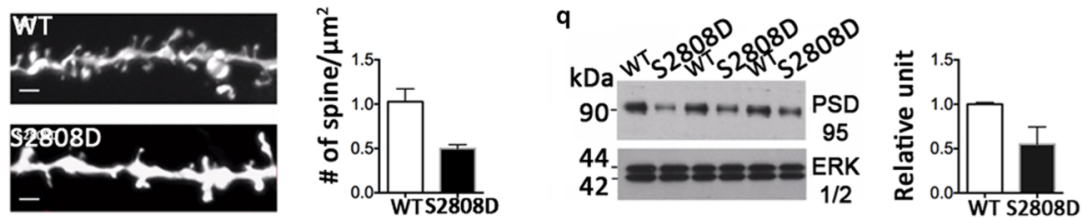

test was performed as in Fig. 3. i Novel object recognition (NOR) test: exploration duration for two identical objects. j Discrimination index after 1-h interval. Data are presented as mean \pm SEM. $\mathbf{k}$, l EPM test, ratios of time spent in the open arm and closed arm and total number of entries. Data are presented as mean \pm SEM. m-o Electrophysiological LTP (m), LTD (n), and fEPSP slope (o) recordings were performed as in Fig. 4. Two-way ANOVA was used for data analyses. WT, $n=14$ slices were from nine mice, S2808D, $n=7$ slices from seven mice, S2808D $+\mathrm{S} 107(\mathrm{~F} 0), n=6$ slices from six mice, S2808D $+\mathrm{S} 107(\mathrm{~F} 2), n=9$ slices from four mice. p Representative image and summary graph of spine density. Spine images were taken from six mice in each genotype. Data were taken from 10 to 20 neurons/mouse. Data were analyzed as mean \pm SEM, $* p<0.05$ versus WT mice. Scale bar: $1 \mu \mathrm{m}$. q Expression of PSD95 in hippocampal samples from the WT (WT) and $R y R 2-S 2808 D^{+/+}$ (S2808D) $(n=3)$ mice were examined by immunoblot analysis. Total ERK1/2 at 42 and $44 \mathrm{kDa}$ served as loading control. Data were analyzed as mean \pm SEM, ${ }^{*} p<0.05$, vs. WT mice. $\mathbf{j}-\mathbf{q}$ data were analyzed using the one-way ANOVA and Tukey's post-test 
$\beta 2$-Adrenergic receptors ( $\beta 2$-ARs) have been implicated in the development of AD [90]. Interestingly, $\beta 2-A R$ gene variants have been identified as risk factors for lateonset $\mathrm{AD}$ [89]. Oxidative stress is also a major contributor to AD pathogenesis $[31,37,83]$. We suggest that RyR2 remodeling likely occurs through synergistic oxidative and $\beta$-adrenergic stimulation. It has already been shown that A $\beta$ stimulates PKA activity and PKA-dependent signaling pathways by activating $\beta$-ARs $[23,39,59,66]$. Conversely, $\beta$-ARs blockers and inhibitors of PKA diminish A $\beta$ production and delay functional decline in AD $[49,68]$. However, the mechanism underlying this functional interplay remains uncertain. Activation of $\beta 2$-ARs enhances $\gamma$-secretase activity and accelerates $A \beta$ plaques formation [54, 90], a process that can be blocked by the specific $\beta 2$ antagonist [90]. Interestingly, $A \beta 42$ peptide binds to the $\mathrm{N}$-terminus of $\beta 2$-ARs [84].

We show in the present study that neuronal RyR2 channels are PKA phosphorylated in both human AD patients and in two murine models of AD. Preventing PKA phosphorylation of RyR in RyR2-S2808A $A^{+/+} \times A P P^{+/-} /$ $\mathrm{PSI}^{+/-}$crossed mice provides strong support for the potential role of the adrenergic signaling cascade in the pathogenesis of AD. Indeed, in the human samples, a major difference in RyR2 biochemistry between non$\mathrm{AD}$ and $\mathrm{AD}$ patient samples is PKA phosphorylation of the RyR2 channel. We noticed the presence of phosphorylated tau (pTau181, and pTau262) in age-matched AD human controls. Indeed, it was previously reported that abnormally phosphorylated tau accumulates as neurofibrillary tangles and neuropil threads in older persons with and without $\mathrm{AD}$ [18].

In accordance with our study, the beneficial effects of genetic knockdown or pharmacologic blockade of $\beta 2-\mathrm{AR}$ were reported in tau [86] and in Tg2576 transgenic mice [21]. Selective targeting of $\beta$-AR to reverse/prevent AD pathology remains, however, controversial. The administration of a $\beta 2-A R$ antagonist has been shown to exacerbate neuropathology and cognitive deficits in a mouse model of $\mathrm{AD}$ [7]. The pharmacological stimulation of $\beta 2-\mathrm{AR}$ has been shown to improve cognitive function and restore synaptic density in a mouse model of Down syndrome [19]. Recently it has also been reported that an enriched environment activates $\beta 2$-ARs and protects against $A \beta$-induced reduction in LTP and prevents A $\beta$ oligomers-mediated hippocampal impairment [46]. Importantly, while it is well established that $\beta$-adrenergic signaling is important for learning and memory, it appears that chronic activation of this cascade may be detrimental.

Intracellular $\mathrm{Ca}^{2+}$ release via RyRs has been proposed to be involved in the regulation of LTD and LTP which represents the cellular basis for learning and memory [1, 25, $67,82]$. A previous study reported that inhibition of RyR channels enhances hippocampal LTD [12]. This finding is consistent with our present data showing reduced LTD in the presence of leaky RyR2 channels. In mice with impaired LTD, Kandel and colleagues reported downregulation of RyRs and up-regulation of inhibitor 1 which inhibits PP1 [25]. Inhibition of PP1 would promote PKA phosphorylation of RyR2 as we found in both human $\mathrm{AD}$ and murine AD models. We show that in AD human brains and in AD-like mice models, the RyR2 macromolecular complex is depleted of both PP1 and its anchoring protein spinophilin $[2,26]$. This is consistent with the fact that the amount of spinophilin is decreased in the AD brain [59]. Here, we show for the first time, in an adult AD mouse model that LTD (memory editing) is reduced, suggesting that a combination of impaired storage of new memories (decreased LTP) combined with reduced memory editing (decreased LTD) contributes to decreased memory flexibility [55] and increased confusion in AD.

It has been reported that $\mathrm{Ca}^{2+}$ plays a role in the production of $\mathrm{A} \beta$ peptides, tau phosphorylation and neurofibrillary tangles in AD [20]. We show that signaling pathways leading to $A \beta$ production and tau phosphorylation are activated in the setting of chronic intracellular $\mathrm{Ca}^{2+}$ leak. Moreover, pharmacologic and genetic fixing RyR2-mediated $\mathrm{Ca}^{2+}$ leak decreased the activation of these signaling pathways leading to reduced $\mathrm{A} \beta$ production and tau phosphorylation. In support of these findings, the RyR active drug dantrolene has been shown to prevent AD-type pathology [91], including a reduction in $\mathrm{A} \beta$ plaques, in some [11, 58, 63], but not all studies [92]. However, the application of dantrolene in clinic for the treatment of $\mathrm{AD}$ is questionable due to adverse side effects associated with its chronic use [47].

Another key finding in the present study is that the expression of a phosphomimetic RyR2-S2808D ${ }^{+/+}$channel in mice results in neuronal intracellular $\mathrm{Ca}^{2+}$ leak associated with cognitive and behavioral deficits. Interestingly, the finding that it takes two generations of fixing RyR2mediated $\mathrm{ER} \mathrm{Ca}^{2+}$ leak (with S107) to show improvement in the AD-like phenotype and the reduction in methylation of hippocampal DNA in the RyR2-S2808D ${ }^{+/+}$mice points toward a potentially strong contribution of $\mathrm{ER} \mathrm{Ca}^{2+}$ leak physiology to epigenetic control [5, 30].

An important question is what is the initiating event in AD? Do leaky RyR2 channels activate a signaling cascade resulting in $A \beta$ plaque deposition and tangle formation that cause $\mathrm{AD}$, or does $\mathrm{A} \beta$ activate RyR2 channels [60] causing an intracellular $\mathrm{Ca}^{2+}$ leak that leads to further pathology? We suggest that an increase in the formation of $A \beta$ peptides in FAD could lead to $A \beta$-dependent $\beta$-adrenergic and oxidative stress. Yet, an age-dependent increase in oxidative stress could also play a role in the disease mechanism of SAD. The finding of leaky RyR2 channels due to post-translational modifications by oxidation and PKA phosphorylation 
Fig. 7 The vicious cycle of Alzheimer's disease neurodegeneration involving $A \beta$, $\beta 2$-adrenergic signaling, and leaky RyR2 channels. ER $\mathrm{Ca}^{2+}$ leak via phosphorylated and oxidized RyR2 channels resulting from synergistic $\mathrm{A} \beta$-dependent $\beta 2$-adrenergic (Box $A)$ and oxidative/nitrosative stress $(B \circ \times B)$ accelerate the neuropathology associated with $\mathrm{AD}$, forming a vicious cycle in which $A \beta$ activates adrenergic and oxidative signaling that promotes ER Ca ${ }^{2+}$ leak via RyR2. This in turn exacerbates $A \beta$ production (Box C). Breaking the cycle using S107 to fix the leaky RyR2 channels slows down the AD disease process, reduces neuropathology and improves cognitive function in $\mathrm{AD}$

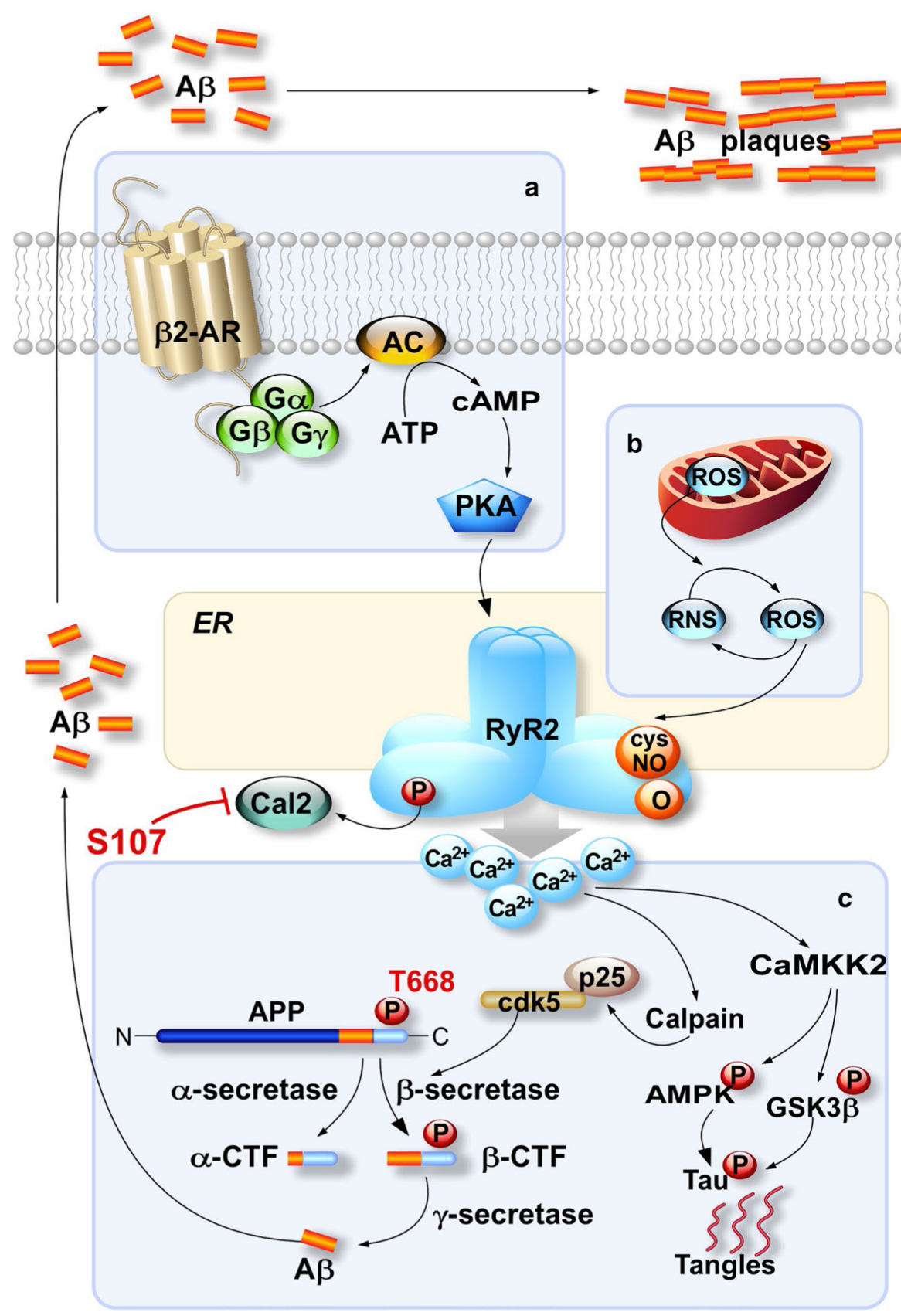

supports the hypothesis that intracellular $\mathrm{Ca}^{2+}$ leak can be an initiating or early factor in the development of $\mathrm{AD}$, particularly in individuals with an underlying predisposition to AD. The age-dependent component of sporadic AD is consistent with the age-dependent ER $\mathrm{Ca}^{2+}$ leak in RyR channels that occurs due to progressive oxidative stress [3]. Data from the present study and from others $[11,58,63]$ showing that RyR-mediated $\mathrm{Ca}^{2+}$ release is upstream of $A \beta$ plaque formation, combined with data suggesting that $A \beta$ can activate RyR channels [60], raise the possibility of a vicious cycle in which leaky RyR 2 channels promote $A \beta$ production and $A \beta$ enhances RyR2 leak (Fig. 7).
Acknowledgements This work was supported by NHLBIR01HL061503 (ARM), NHLBI-R01HL102040 (ARM), NIAMSR01AR060037 (ARM), NIH T32 HL120826 (ARM), NINDSR25NS076445 (ARM), the Fondation Leducq and a generous donation from Carol Stix (ARM); Inserm, Philipp Foundation and Schaefer Award from Columbia University (AL); LECMA (Ligue Européenne Contre la Maladie d'Alzheimer) (MC); LABEX (Excellence Laboratory, Program Investment for the Future), DISTALZ (Development of Innovative Strategies for a Transdisciplinary approach to Alzheimer's disease) (FC), the University Hospital Federation (FHU)-OncoAge (FC), the Fondation Pompidou (FC); NIA-RO1AG030205 (GES). The authors thank Steven Siegelbaum, Eric Kandel and Richard Axel for helpful discussions and comments on the paper and Valerie Scheuermann for preliminary biochemical experiments. 
Author contributions ARM and MC independently conceived the study. XL, MC, FC, AL and ARM designed the studies, analyzed data and wrote the manuscript. XL conducted studies on $A P P^{+/-} / P S 1^{+/-}$, $R y R 2-S 2808 D^{+/+}, R y R 2-S 2808 A^{+/+}$and $R y R 2-S 2808 A^{+/+} \times A P P^{+/-}$' $P S 1^{+/-}$mouse colonies. SR designed and conducted biochemistry assays of RyR2. MC, AL, RB, IL, CB and FD conducted studies on the $3 \times \mathrm{Tg}$-AD mice. AM, NS and AL designed and conducted RyR2 single-channel analyses. AFT conducted the immunohistochemistry experiments on $\mathrm{APP} \mathrm{P}^{+/-} / \mathrm{PS} 1^{+/-}$and $\mathrm{RyR} 2-\mathrm{S} 2808 \mathrm{~A}^{+/+} \times \mathrm{APP}^{+/-} /$ $P S 1^{+/-}$mice and analyzed the data. CAB, SC and GES designed, conducted and performed patch-clamp $\mathrm{Ca}^{2+}$ imaging and sEPSP experiments and analyzed the data. OA analyzed the electrophysiological recordings and behavioral studies. MS designed the experiments, analyzed data and edited the manuscript.

\section{Compliance with ethical standards}

Ethical approval All applicable international, national and/or institutional guidelines for the care and use of animals were followed. All procedures performed in studies involving animals were in accordance with the ethical standards of the institution or practice at which the studies were conducted.

In vivo experiments were performed in accordance with the regulations of the Institutional Animal Care and Use Committee of Columbia University $\left(\mathrm{APP}^{+/-} / \mathrm{PS}^{+/-}, R y R 2-S 2808 A^{+/+}\right.$, and $R y R 2-S 2808 D^{+/+}$ mice) and with the guidelines established by the European Community Council (Directive of November 24th, 1986) and approved by the Nice University Animal care and use Committee and the National Council on animal care of the Ministry of Health (Project No: NCE/2013-152) $(3 \times \mathrm{Tg}-\mathrm{AD}$ mice $)$.

All procedures performed in studies involving human participants were in accordance with the ethical standards of the institutional and/ or national research committee and with the 1964 Helsinki Declaration and its later amendments or comparable ethical studies.

Informed consent Informed consent for tissue donation for research was obtained by the brain banks under their approval procedures.

Conflict of interest ARM is a board member and owns shares in ARMGO Pharma Inc., which is targeting RyR channels for therapeutic purposes.

\section{References}

1. Adasme T, Haeger P, Paula-Lima AC, Espinoza I, Casas-Alarcon MM, Carrasco MA, Hidalgo C (2011) Involvement of ryanodine receptors in neurotrophin-induced hippocampal synaptic plasticity and spatial memory formation. Proc Natl Acad Sci USA 108:3029-3034. doi:10.1073/pnas.1013580108

2. Allen PB, Ouimet CC, Greengard P (1997) Spinophilin, a novel protein phosphatase 1 binding protein localized to dendritic spines. Proc Natl Acad Sci USA 94:9956-9961

3. Andersson DC, Betzenhauser MJ, Reiken S, Meli AC, Umanskaya A, Xie W, Shiomi T, Zalk R, Lacampagne A, Marks AR (2011) Ryanodine receptor oxidation causes intracellular calcium leak and muscle weakness in aging. Cell Metab 14:196207. doi:10.1016/j.cmet.2011.05.014

4. Barelli H, Lebeau A, Vizzavona J, Delaere P, Chevallier N, Drouot C, Marambaud P, Ancolio K, Buxbaum JD, Khorkova $O$ et al (1997) Characterization of new polyclonal antibodies specific for 40 and 42 amino acid-long amyloid beta peptides: their use to examine the cell biology of presenilins and the immunohistochemistry of sporadic Alzheimer's disease and cerebral amyloid angiopathy cases. Mol Med 3:695-707

5. Bennett DA, Yu L, Yang J, Srivastava GP, Aubin C, De Jager PL (2015) Epigenomics of Alzheimer's disease. Transl Res 165:200-220. doi:10.1016/j.trs1.2014.05.006

6. Berridge MJ (2011) Calcium signalling and Alzheimer's disease. Neurochem Res 36:1149-1156. doi:10.1007/s11064-010-0371-4

7. Branca C, Wisely EV, Hartman LK, Caccamo A, Oddo S (2014) Administration of a selective beta 2 adrenergic receptor antagonist exacerbates neuropathology and cognitive deficits in a mouse model of Alzheimer's disease. Neurobiol Aging 35:27262735. doi:10.1016/j.neurobiolaging.2014.06.011

8. Briggs CA, Schneider C, Richardson JC, Stutzmann GE (2013) beta amyloid peptide plaques fail to alter evoked neuronal calcium signals in APP/PS1 Alzheimer's disease mice. Neurobiol Aging 34:1632-1643. doi:10.1016/j. neurobiolaging.2012.12.013

9. Brillantes AB, Ondrias K, Scott A, Kobrinsky E, Ondriasova E, Moschella MC, Jayaraman T, Landers M, Ehrlich BE, Marks AR (1994) Stabilization of calcium release channel (ryanodine receptor) function by FK506-binding protein. Cell 77:513-523

10. Bruno AM, Huang JY, Bennett DA, Marr RA, Hastings ML, Stutzmann GE (2012) Altered ryanodine receptor expression in mild cognitive impairment and Alzheimer's disease. Neurobiol Aging 33(1001):e1001-e1006. doi:10.1016/j. neurobiolaging.2011.03.011

11. Chakroborty S, Briggs C, Miller MB, Goussakov I, Schneider C, Kim J, Wicks J, Richardson JC, Conklin V, Cameransi BG et al (2012) Stabilizing ER $\mathrm{Ca}(2+)$ Channel Function as an Early Preventative Strategy for Alzheimer's Disease. PLoS One 7:e52056. doi:10.1371/journal.pone.0052056

12. Chakroborty S, Kim J, Schneider C, Jacobson C, Molgo J, Stutzmann GE (2012) Early presynaptic and postsynaptic calcium signaling abnormalities mask underlying synaptic depression in presymptomatic Alzheimer's disease mice. J Neurosci 32:83418353. doi:10.1523/JNEUROSCI.0936-12.2012

13. Chakroborty S, Stutzmann GE (2014) Calcium channelopathies and Alzheimer's disease: insight into therapeutic success and failures. Eur J Pharmacol 739:83-95. doi:10.1016/j.ejphar.2013.11.012

14. Chan SL, Mayne M, Holden CP, Geiger JD, Mattson MP (2000) Presenilin-1 mutations increase levels of ryanodine receptors and calcium release in PC12 cells and cortical neurons. J Biol Chem 275:18195-18200. doi:10.1074/jbc.M000040200

15. Cheung KH, Shineman D, Muller M, Cardenas C, Mei L, Yang J, Tomita T, Iwatsubo T, Lee VM, Foskett JK (2008) Mechanism of $\mathrm{Ca}^{2+}$ disruption in Alzheimer's disease by presenilin regulation of InsP3 receptor channel gating. Neuron 58:871-883. doi:10.1016/j.neuron.2008.04.015

16. Colquhoun D, Hawkes AG (1982) On the stochastic properties of bursts of single ion channel openings and of clusters of bursts. Philos Trans R Soc Lond B Biol Sci 300:1-59

17. Copello JA, Barg S, Onoue H, Fleischer S (1997) Heterogeneity of $\mathrm{Ca}^{2+}$ gating of skeletal muscle and cardiac ryanodine receptors. Biophys $\mathbf{J}$ 73:141-156. doi:10.1016/ S0006-3495(97)78055-X

18. Crary JF, Trojanowski JQ, Schneider JA, Abisambra JF, Abner EL, Alafuzoff I, Arnold SE, Attems J, Beach TG, Bigio EH et al (2014) Primary age-related tauopathy (PART): a common pathology associated with human aging. Acta Neuropathol 128:755-766. doi:10.1007/s00401-014-1349-0

19. Dang V, Medina B, Das D, Moghadam S, Martin KJ, Lin B, Naik P, Patel D, Nosheny R, Wesson Ashford J et al (2014) Formoterol, a long-acting beta 2 adrenergic agonist, improves cognitive function and promotes dendritic complexity in a mouse model of Down syndrome. Biol Psychiatry 75:179-188. doi:10.1016/j. biopsych.2013.05.024 
20. Del Prete D, Checler F, Chami M (2014) Ryanodine receptors: physiological function and deregulation in Alzheimer disease. Mol Neurodegener 9:21. doi:10.1186/1750-1326-9-21

21. Dobarro M, Gerenu G, Ramirez MJ (2013) Propranolol reduces cognitive deficits, amyloid and tau pathology in Alzheimer's transgenic mice. Int J Neuropsychopharmacol 16:2245-2257. doi:10.1017/S1461145713000631

22. Duff K, Eckman C, Zehr C, Yu X, Prada CM, Perez-tur J, Hutton M, Buee L, Harigaya Y, Yager D et al (1996) Increased amyloidbeta42(43) in brains of mice expressing mutant presenilin 1. Nature 383:710-713. doi:10.1038/383710a0

23. Echeverria V, Ducatenzeiler A, Chen $\mathrm{CH}$, Cuello $\mathrm{AC}$ (2005) Endogenous beta-amyloid peptide synthesis modulates cAMP response element-regulated gene expression in PC12 cells. Neuroscience 135:1193-1202. doi:10.1016/j. neuroscience.2005.06.057

24. Etcheberrigaray R, Hirashima N, Nee L, Prince J, Govoni S, Racchi M, Tanzi RE, Alkon DL (1998) Calcium responses in fibroblasts from asymptomatic members of Alzheimer's disease families. Neurobiol Dis 5:37-45. doi:10.1006/nbdi.1998.0176

25. Etkin A, Alarcon JM, Weisberg SP, Touzani K, Huang YY, Nordheim A, Kandel ER (2006) A role in learning for SRF: deletion in the adult forebrain disrupts LTD and the formation of an immediate memory of a novel context. Neuron 50:127-143. doi:10.1016/j.neuron.2006.03.013

26. Feng J, Yan Z, Ferreira A, Tomizawa K, Liauw JA, Zhuo M, Allen PB, Ouimet CC, Greengard P (2000) Spinophilin regulates the formation and function of dendritic spines. Proc Natl Acad Sci USA 97:9287-9292

27. Flammang B, Pardossi-Piquard R, Sevalle J, Debayle D, DabertGay AS, Thevenet A, Lauritzen I, Checler F (2012) Evidence that the amyloid-beta protein precursor intracellular domain, AICD, derives from beta-secretase-generated C-terminal fragment. J Alzheimers Dis 30:145-153. doi:10.3233/JAD-2012-112186

28. Flucher BE, Andrews SB, Fleischer S, Marks AR, Caswell A, Powell JA (1993) Triad formation: organization and function of the sarcoplasmic reticulum calcium release channel and triadin in normal and dysgenic muscle in vitro. J Cell Biol 123:1161-1174

29. Francis YI, Fa M, Ashraf H, Zhang H, Staniszewski A, Latchman DS, Arancio O (2009) Dysregulation of histone acetylation in the APP/PS1 mouse model of Alzheimer's disease. J Alzheimers Dis 18:131-139. doi:10.3233/JAD-2009-1134

30. Gapp K, Woldemichael BT, Bohacek J, Mansuy IM (2014) Epigenetic regulation in neurodevelopment and neurodegenerative diseases. Neuroscience 264:99-111. doi:10.1016/j. neuroscience.2012.11.040

31. Ghosh D, LeVault KR, Barnett AJ, Brewer GJ (2012) A reversible early oxidized redox state that precedes macromolecular ROS damage in aging nontransgenic and $3 \times \mathrm{Tg}-\mathrm{AD}$ mouse neurons. J Neurosci 32:5821-5832. doi:10.1523/ JNEUROSCI.6192-11.2012

32. Giannini G, Conti A, Mammarella S, Scrobogna M, Sorrentino V (1995) The ryanodine receptor/calcium channel genes are widely and differentially expressed in murine brain and peripheral tissues. J Cell Biol 128:893-904

33. Gong B, Cao Z, Zheng P, Vitolo OV, Liu S, Staniszewski A, Moolman D, Zhang H, Shelanski M, Arancio O (2006) Ubiquitin hydrolase Uch-L1 rescues beta-amyloid-induced decreases in synaptic function and contextual memory. Cell 126:775788. doi:10.1016/j.cell.2006.06.046

34. Goslin K (1991) Rat hippocampal neurons in low-density culture. MIT Press, Cambridge, pp 251-281

35. Goussakov I, Miller MB, Stutzmann GE (2010) NMDA-mediated $\mathrm{Ca}(2+)$ influx drives aberrant ryanodine receptor activation in dendrites of young Alzheimer's disease mice. J Neurosci 30:12128-12137. doi:10.1523/JNEUROSCI.2474-10.2010
36. Heck A, Fastenrath M, Coynel D, Auschra B, Bickel H, Freytag V, Gschwind L, Hartmann F, Jessen F, Kaduszkiewicz Het al (2015) Genetic analysis of association between calcium signaling and hippocampal activation, memory performance in the young and old, and risk for sporadic Alzheimer disease. JAMA Psychiatry. doi:10.1001/jamapsychiatry.2015.1309

37. Hidalgo C, Carrasco MA (2011) Redox control of brain calcium in health and disease. Antioxid Redox Signal 14:12031207. doi:10.1089/ars.2010.3711

38. Hsiao K, Chapman P, Nilsen S, Eckman C, Harigaya Y, Younkin S, Yang F, Cole G (1996) Correlative memory deficits, Abeta elevation, and amyloid plaques in transgenic mice. Science 274:99-102

39. Igbavboa U, Johnson-Anuna LN, Rossello X, Butterick TA, Sun GY, Wood WG (2006) Amyloid beta-protein 1-42 increases cAMP and apolipoprotein E levels which are inhibited by beta1 and beta2-adrenergic receptor antagonists in mouse primary astrocytes. Neuroscience 142:655-660. doi:10.1016/j. neuroscience.2006.06.056

40. Lalonde R, Kim HD, Maxwell JA, Fukuchi K (2005) Exploratory activity and spatial learning in 12-month-old APP(695) SWE/co+ PS1/DeltaE9 mice with amyloid plaques. Neurosci Lett 390:87-92. doi:10.1016/j.neulet.2005.08.028

41. Lauritzen I, Pardossi-Piquard R, Bauer C, Brigham E, Abraham JD, Ranaldi S, Fraser P, St-George-Hyslop P, Le Thuc O, Espin V et al (2012) The beta-secretase-derived C-terminal fragment of betaAPP, C99, but not Abeta, is a key contributor to early intraneuronal lesions in triple-transgenic mouse hippocampus. J Neurosci 32:16243-16255a. doi:10.1523/ JNEUROSCI.2775-12.2012

42. LeDoux JE (2000) Emotion circuits in the brain. Annu Rev Neurosci 23:155-184. doi:10.1146/annurev.neuro.23.1.155

43. Leissring MA, Murphy MP, Mead TR, Akbari Y, Sugarman MC, Jannatipour M, Anliker B, Muller U, Saftig P, De Strooper $B$ et al (2002) A physiologic signaling role for the gamma -secretase-derived intracellular fragment of APP. Proc Natl Acad Sci USA 99:4697-4702. doi:10.1073/pnas.072033799

44. Leissring MA, Parker I, LaFerla FM (1999) Presenilin-2 mutations modulate amplitude and kinetics of inositol 1, 4,5-trisphosphate-mediated calcium signals. J Biol Chem 274:32535-32538

45. Li R, Lindholm K, Yang LB, Yue X, Citron M, Yan R, Beach T, Sue L, Sabbagh M, Cai H et al (2004) Amyloid beta peptide load is correlated with increased beta-secretase activity in sporadic Alzheimer's disease patients. Proc Natl Acad Sci USA 101:3632-3637. doi:10.1073/pnas.0205689101

46. Li S, Jin M, Zhang D, Yang T, Koeglsperger T, Fu H, Selkoe DJ (2013) Environmental novelty activates beta2-adrenergic signaling to prevent the impairment of hippocampal LTP by Abeta oligomers. Neuron 77:929-941. doi:10.1016/j.neuron.2012.12.040

47. Liang L, Wei H (2015) Dantrolene, a treatment for Alzheimer disease? Alzheimer Dis Assoc Disord 29:1-5. doi:10.1097/ WAD.0000000000000076

48. Liu X, Betzenhauser MJ, Reiken S, Meli AC, Xie W, Chen BX, Arancio O, Marks AR (2012) Role of leaky neuronal ryanodine receptors in stress- induced cognitive dysfunction. Cell 150:1055-1067. doi:10.1016/j.cell.2012.06.052

49. Marambaud P, Ancolio K, Alves da Costa C, Checler F (1999) Effect of protein kinase A inhibitors on the production of Abeta40 and Abeta42 by human cells expressing normal and Alzheimer's disease-linked mutated betaAPP and presenilin 1. Br J Pharmacol 126:1186-1190. doi:10.1038/sj.bjp.0702406

50. Marks AR (1997) Intracellular calcium-release channels: regulators of cell life and death. Am J Physiol 272:H597-H605

51. Marx SO, Reiken S, Hisamatsu Y, Gaburjakova M, Gaburjakova J, Yang YM, Rosemblit N, Marks AR (2001) 
Phosphorylation-dependent regulation of ryanodine receptors: a novel role for leucine/isoleucine zippers. J Cell Biol 153:699-708

52. Marx SO, Reiken S, Hisamatsu Y, Jayaraman T, Burkhoff D, Rosemblit N, Marks AR (2000) PKA phosphorylation dissociates FKBP12.6 from the calcium release channel (ryanodine receptor): defective regulation in failing hearts. Cell 101:365-376

53. Moolman DL, Vitolo OV, Vonsattel JP, Shelanski ML (2004) Dendrite and dendritic spine alterations in Alzheimer models. J Neurocytol 33:377-387. doi:10.1023/B:N EUR.0000044197.83514.64

54. Ni Y, Zhao X, Bao G, Zou L, Teng L, Wang Z, Song M, Xiong J, Bai Y, Pei G (2006) Activation of beta2-adrenergic receptor stimulates gamma-secretase activity and accelerates amyloid plaque formation. Nat Med 12:1390-1396. doi:10.1038/ nm1485

55. Nicholls RE, Alarcon JM, Malleret G, Carroll RC, Grody M, Vronskaya S, Kandel ER (2008) Transgenic mice lacking NMDAR-dependent LTD exhibit deficits in behavioral flexibility. Neuron 58:104-117. doi:10.1016/j.neuron.2008.01.039

56. Niu Y, Su Z, Zhao C, Song B, Zhang X, Zhao N, Shen X, Gong $Y$ (2009) Effect of amyloid beta on capacitive calcium entry in neural 2a cells. Brain Res Bull 78:152-157. doi:10.1016/j. brainresbull.2008.10.003

57. Oddo S, Caccamo A, Shepherd JD, Murphy MP, Golde TE, Kayed R, Metherate R, Mattson MP, Akbari Y, LaFerla FM (2003) Triple-transgenic model of Alzheimer's disease with plaques and tangles: intracellular Abeta and synaptic dysfunction. Neuron 39:409-421

58. Oules B, Del Prete D, Greco B, Zhang X, Lauritzen I, Sevalle J, Moreno S, Paterlini-Brechot P, Trebak M, Checler F et al (2012) Ryanodine receptor blockade reduces amyloid-beta load and memory impairments in Tg2576 mouse model of Alzheimer disease. J Neurosci 32:11820-11834. doi:10.1523/ JNEUROSCI.0875-12.2012

59. Palavicini JP, Wang H, Bianchi E, Xu S, Rao JS, Kang DE, Lakshmana MK (2013) RanBP9 aggravates synaptic damage in the mouse brain and is inversely correlated to spinophilin levels in Alzheimer's brain synaptosomes. Cell Death Dis 4:e667. doi:10.1038/cddis.2013.183

60. Paula-Lima AC, Adasme T, SanMartin C, Sebollela A, Hetz C, Carrasco MA, Ferreira ST, Hidalgo C (2011) Amyloid beta-peptide oligomers stimulate RyR-mediated $\mathrm{Ca}^{2+}$ release inducing mitochondrial fragmentation in hippocampal neurons and prevent RyR-mediated dendritic spine remodeling produced by BDNF. Antioxid Redox Signal 14:1209-1223. doi:10.1089/ars.2010.3287

61. Paula-Lima AC, Hidalgo C (2013) Amyloid beta-peptide oligomers, ryanodine receptor-mediated $\mathrm{Ca}(2+)$ release, and Wnt-5a/Ca(2+) signaling: opposing roles in neuronal mitochondrial dynamics? Front Cell Neurosci 7:120. doi:10.3389/ fncel.2013.00120

62. Paylor R, Tracy R, Wehner J, Rudy JW (1994) DBA/2 and C57BL/6 mice differ in contextual fear but not auditory fear conditioning. Behav Neurosci 108:810-817

63. Peng J, Liang G, Inan S, Wu Z, Joseph DJ, Meng Q, Peng Y, Eckenhoff MF, Wei H (2012) Dantrolene ameliorates cognitive decline and neuropathology in Alzheimer triple transgenic mice. Neurosci Lett 516:274-279. doi:10.1016/j.neulet.2012.04.008

64. Pilpel Y, Segal M (2004) Activation of PKC induces rapid morphological plasticity in dendrites of hippocampal neurons via Rac and Rho-dependent mechanisms. Eur J Neurosci 19:31513164. doi:10.1111/j.0953-816X.2004.03380.x

65. Popugaeva E, Bezprozvanny I (2013) Role of endoplasmic reticulum $\mathrm{Ca}^{2+}$ signaling in the pathogenesis of Alzheimer disease. Front Mol Neurosci 6:29. doi:10.3389/fnmol.2013.00029
66. Prapong T, Uemura E, Hsu WH (2001) G protein and cAMPdependent protein kinase mediate amyloid beta-peptide inhibition of neuronal glucose uptake. Experimental neurology 167:59-64. doi:10.1006/exnr.2000.7519

67. Reyes M, Stanton PK (1996) Induction of hippocampal long-term depression requires release of $\mathrm{Ca}^{2+}$ from separate presynaptic and postsynaptic intracellular stores. J Neurosci 16:5951-5960

68. Rosenberg PB, Mielke MM, Tschanz J, Cook L, Corcoran C, Hayden KM, Norton M, Rabins PV, Green RC, Welsh-Bohmer KA et al (2008) Effects of cardiovascular medications on rate of functional decline in Alzheimer disease. Am $\mathbf{J}$ Geriatr Psychiatry 16:883-892. doi:10.1097/JGP.0b013e318181276a

69. Saito K, Elce JS, Hamos JE, Nixon RA (1993) Widespread activation of calcium-activated neutral proteinase (calpain) in the brain in Alzheimer disease: a potential molecular basis for neuronal degeneration. Proc Natl Acad Sci USA 90:2628-2632

70. Santulli G, Marks AR (2015) Essential Roles of intracellular calcium release channels in muscle, brain, metabolism, and aging. Curr Mol Pharmacol 8:206-222

71. Schubert V, Da Silva JS, Dotti CG (2006) Localized recruitment and activation of RhoA underlies dendritic spine morphology in a glutamate receptor-dependent manner. J Cell Biol 172:453467. doi:10.1083/jcb.200506136

72. Shan J, Betzenhauser MJ, Kushnir A, Reiken S, Meli AC, Wronska A, Dura M, Chen BX, Marks AR (2010) Role of chronic ryanodine receptor phosphorylation in heart failure and beta-adrenergic receptor blockade in mice. J Clin Invest 120:4375-4387. doi: 10.1172/JCI37649

73. Shan J, Kushnir A, Betzenhauser MJ, Reiken S, Li J, Lehnart SE, Lindegger N, Mongillo M, Mohler PJ, Marks AR (2010) Phosphorylation of the ryanodine receptor mediates the cardiac fight or flight response in mice. J Clin Invest 120:4388-4398. doi:10.1172/JCI32726

74. Shilling D, Muller M, Takano H, Mak DO, Abel T, Coulter DA, Foskett JK (2014) Suppression of InsP3 receptor-mediated $\mathrm{Ca}^{2+}$ signaling alleviates mutant presenilin-linked familial Alzheimer's disease pathogenesis. J Neurosci 34:6910-6923. doi:10.1523/JNEUROSCI.5441-13.2014

75. Shrestha BR, Vitolo OV, Joshi P, Lordkipanidze T, Shelanski M, Dunaevsky A (2006) Amyloid beta peptide adversely affects spine number and motility in hippocampal neurons. Mol Cell Neurosci 33:274-282. doi:10.1016/j.mcn.2006.07.011

76. Smith DL, Pozueta J, Gong B, Arancio O, Shelanski M (2009) Reversal of long-term dendritic spine alterations in Alzheimer disease models. Proc Natl Acad Sci USA 106:16877-16882. doi:10.1073/pnas.0908706106

77. Stutzmann GE, Caccamo A, LaFerla FM, Parker I (2004) Dysregulated IP3 signaling in cortical neurons of knock-in mice expressing an Alzheimer's-linked mutation in presenilinl results in exaggerated $\mathrm{Ca}^{2+}$ signals and altered membrane excitability. J Neurosci 24:508-513. doi:10.1523/JNEUROSCI.4386-03.2004

78. Stutzmann GE, Smith I, Caccamo A, Oddo S, Laferla FM, Parker I (2006) Enhanced ryanodine receptor recruitment contributes to $\mathrm{Ca}^{2+}$ disruptions in young, adult, and aged Alzheimer's disease mice. J Neurosci 26:5180-5189. doi:10.1523/ JNEUROSCI.0739-06.2006

79. Supnet C, Grant J, Kong H, Westaway D, Mayne M (2006) Amyloid-beta-(1-42) increases ryanodine receptor-3 expression and function in neurons of TgCRND8 mice. J Biol Chem 281:38440-38447. doi:10.1074/jbc.M606736200

80. Tashiro A, Minden A, Yuste R (2000) Regulation of dendritic spine morphology by the rho family of small GTPases: antagonistic roles of Rac and Rho. Cereb Cortex 10:927-938

81. Texido L, Martin-Satue M, Alberdi E, Solsona C, Matute C (2011) Amyloid beta peptide oligomers directly activate NMDA receptors. Cell Calcium 49:184-190. doi:10.1016/j.ceca.2011.02.001 
82. Unni VK, Zakharenko SS, Zablow L, DeCostanzo AJ, Siegelbaum SA (2004) Calcium release from presynaptic ryanodinesensitive stores is required for long-term depression at hippocampal CA3-CA3 pyramidal neuron synapses. J Neurosci 24:9612-9622. doi:10.1523/JNEUROSCI.5583-03.2004

83. von Bernhardi R, Eugenin J (2012) Alzheimer's disease: redox dysregulation as a common denominator for diverse pathogenic mechanisms. Antioxid Redox Signal 16:974-1031. doi:10.1089/ ars.2011.4082

84. Wang D, Govindaiah G, Liu R, De Arcangelis V, Cox CL, Xiang YK (2010) Binding of amyloid beta peptide to beta2 adrenergic receptor induces PKA-dependent AMPA receptor hyperactivity. FASEB J 24:3511-3521. doi:10.1096/fj.10-156661

85. Wehrens XH, Lehnart SE, Reiken SR, Deng SX, Vest JA, Cervantes D, Coromilas J, Landry DW, Marks AR (2004) Protection from cardiac arrhythmia through ryanodine receptor-stabilizing protein calstabin2. Science 304:292-296. doi:10.1126/ science. 1094301

86. Wisely EV, Xiang YK, Oddo S (2014) Genetic suppression of beta2-adrenergic receptors ameliorates tau pathology in a mouse model of tauopathies. Hum Mol Genet 23:4024-4034. doi:10.1093/hmg/ddu116

87. Wu B, Yamaguchi H, Lai FA, Shen J (2013) Presenilins regulate calcium homeostasis and presynaptic function via ryanodine receptors in hippocampal neurons. Proc Natl Acad Sci USA 110:15091-15096. doi:10.1073/pnas.1304171110

88. Yang LB, Lindholm K, Yan R, Citron M, Xia W, Yang XL, Beach T, Sue L, Wong P, Price D et al (2003) Elevated beta-secretase expression and enzymatic activity detected in sporadic Alzheimer disease. Nat Med 9:3-4. doi:10.1038/nm0103-3

89. Yu JT, Tan L, Ou JR, Zhu JX, Liu K, Song JH, Sun YP (2008) Polymorphisms at the beta2-adrenergic receptor gene influence Alzheimer's disease susceptibility. Brain Res 1210:216-222. doi: 10.1016/j.brainres.2008.03.019

90. Yu NN, Wang XX, Yu JT, Wang ND, Lu RC, Miao D, Tian Y, Tan L (2010) Blocking beta2-adrenergic receptor attenuates acute stress-induced amyloid beta peptides production. Brain Res 1317:305-310. doi:10.1016/j.brainres.2009.12.087

91. Zhang H, Liu J, Sun S, Pchitskaya E, Popugaeva E, Bezprozvanny I (2015) Calcium signaling, excitability, and synaptic plasticity defects in a mouse model of Alzheimer's disease. J Alzheimers Dis 45:561-580. doi:10.3233/JAD-142427

92. Zhang H, Sun S, Herreman A, De Strooper B, Bezprozvanny I (2010) Role of presenilins in neuronal calcium homeostasis. J Neurosci 30:8566-8580. doi:10.1523/ JNEUROSCI.1554-10.2010 